\title{
Evidence of mingling between contrasting magmas in a deep plutonic environment: the example of Várzea Alegre, in the Ribeira Mobile Belt, Espírito Santo, Brazil
}

\author{
SILVIA R. MEDEIROS ${ }^{1,2}$, CRISTINA M. WIEDEMANN-LEONARDOS ${ }^{2}$ and SIMON VRIEND ${ }^{3}$ \\ ${ }^{1}$ Department of Geology IGEO/UFRJ, Ilha do Fundão, Cidade Universitária, 21945-970 Rio de Janeiro, RJ, Brazil \\ ${ }^{2}$ Department of Geology, IGEO/UnB, Cx. Postal 04350, Asa Norte, 70919-970 Brasília, DF, Brazil \\ ${ }^{3}$ Department of Geochemistry, Faculteit Aardwetenschappen, Budapestlaan 4 De Uithof Postbus 80021, \\ 3508 TA Utrecht, The Netherlands
}

Manuscript received on September 3, 1999; accepted for publication on July 14, 2000;

contributed by CRISTINA M. WIEDEMANN-LEONARDOS*

\begin{abstract}
At the end of the geotectonic cycle that shaped the northern segment of the Ribeira Mobile Belt (Upper Proterozoic to Paleozoic age), a late to post-collisional set of plutonic complexes, consisting of a wide range of lithotypes, intruded all metamorphic units.

The Várzea Alegre Intrusive Complex is a post-collisional complex. The younger intrusion consists of an inversely zoned multistage structure envolved by a large early emplaced ring of megaporphyritic charnoenderbitic rocks.

The combination of field, petrographic and geochemical data reveals the presence of at least two different series of igneous rocks. The first originated from the partial melting of the mantle. This was previously enriched in incompatible elements, low and intermediate REE and some HFS-elements. A second enrichment in LREE and incompatible elements in this series was due to the mingling with a crustal granitic magma. This mingling process changed the composition of the original tholeiitic magma towards a medium-K calc-alkalic magma to produce a suite of basic to intermediate rock types.

The granitic magma from the second high-K, calc-alkalic suite originated from the partial melting of the continental crust, but with strong influence of mantle-derived melts.
\end{abstract}

Key words: Magma mingling, post-collisional magmatism, Ribeira Belt.

\section{INTRODUCTION}

Most of the history of the geological evolution of the coastal region in the states of Rio de Janeiro and Espírito Santo, in Brazil, is comprised of the development of a Mobile Belt of Upper Proterozoic to Paleozoic age (Cordani et al. 1973, Söllner et al. 1991, Machado et al. 1996). In the cen-

\footnotetext{
* Member of Academia Brasileira de Ciências

Correspondence to: Silvia R. Medeiros at IGEO/UnB

E-mail: silviar@unb.br,wiedeman@unb.br
}

tral part of Espírito Santo, discussed in this paper, the roots of this Mobile Belt are exposed revealing considerable amounts of granulitic and charnoenderbitic rocks interfingered with granitic, granodioritic and kinzigitic gneisses, containing sillimanite, cordierite and garnet.

During the main collisional period great volumes of calc-alkalic magma was produced and a syncollisional magmatic arc was formed (Bayer et al. 1986, Wiedemann et al. 1986, Tuller 1993, Cam- 
pos Neto \& Figueiredo 1995, Pedrosa-Soares et al. 1999).

The whole sequence of high grade gneisses and granulites, of magmatic as well as sedimentary origin, strikes in the NE-SW direction. The high grade metamorphism (590 to $564 \mathrm{Ma}$ ) was accompanied by the development of a metamorphic or migmatitic layering and tight isoclinal folds, refolded into large scale style of folds with amplitudes up to $10 \mathrm{~km}$. Ductile shear zones are superimposed on the previous deformations and locally obliterate them (Lammerer 1987, Fritzer 1991, Cunningham et al. 1998). Younger ages (around $560 \mathrm{Ma}$ ) obtained for charnoenderbitic rocks from the Coastal Complex in this region have been related to the thermal evolution of the metamorphism, which produced medium to low presssures granulites from previous high-amphibolite facies and migmatitic gneisses. (Sluitner \& Weber-Diefenbach 1989, Söllner et al. 1989, Fritzer 1991, Seidensticker \& Wiedemann 1992).

At the end of the Brasiliano geotectonic cycle, a late to post-collisional set of plutonic complexes, consisting of a wide range of lithotypes grading from gabbros to monzosyenites, intruded all metamorphic units (Wiedemann 1993). Extensive magma mingling and mixing, in most composite plutons in this region, has been a complicating factor for the solution of the original compositions of the primary magmas involved. Studies on the whole rock chemistry of the late to post-tectonic intrusive complexes point towards three groups of magmas: tholeiitic, medium- to high-K calc-alkalic/alkali-calcic and very high-K alcali-calcic to alkalic suites (Wiedemann 1993).

X-ray fluorescence, ICP and INAA analysis of major, minor and trace elements, including Rare Earth elements, were carried out to study the geochemical signatures of the different lithotypes. Microprobe analysis of the minerals were undertaken in order to further investigate the nature of the primary magmas involved in the mingling process as well as the mixing process on a crystal scale.

\section{THE VÁRZEA ALEGRE INTRUSIVE COMPLEX (VAIC)}

The Várzea Alegre Intrusive Complex (VAIC Fig. 1) crops out over an area of about $150 \mathrm{~km}^{2}$. It consists of a multipulse structure, where a first charnoenderbitic pluton (charnoenderbitic outer rim) discordantly intruded the enclosing gneisses and granulites. A second younger pluton formed by the hypersthene-gabbro and a composite body of quartz-diorite, quartz-monzodiorite, coarse-grained megaporphiritic granite and a small body of sphenequartz-syenite intrudes the first charnoenderbitic outer rim. Compared with other igneous charnockitoids from this region (as for example those from the Serra do Valentim; Fritzer 1991), the charnoenderbitic rocks from Várzea Alegre show very similar field and petrographic characteristics (Mendes et al. 1999).

According to Bilal et al. (1998), the neighboring charnockitic intrusions of Ibituba and Itapina massifs consolidated at 535-520 Ma. (U-Pb in zircons). Therefore the intrusion of the charnoenderbitic outer shell is considered to have happened at the end or after of the main regional high grade metamorphic phase.

The charnoenderbites from Várzea Alegre are clearly deep green in color and have a mainly granodioritic composition (Mendes et al. 1997, Mendes et al. 1999). They may locally vary between opdalite (hyperthene granodiorite), jotunite (hypersthene monzodiorite), opx-quartz diorite and quartz mangerite (quartz monzonite). Along the contact to the enclosing rocks the foliation is well marked and sharp intrusive contacts with the enclosing granitictonalitic gnaisses were observed. The igneous border foliation and the schistosity of the gneisses are generally dipping towards the center of the pluton (Fig. 1). When observed, the contact between the charnoenderbitic outer rim and magmatites of the inner domain is ductile and interfingered.

The second intrusion (inner domain) crystallized around $508 \pm 12 \mathrm{Ma}$. $\left({ }^{87} \mathrm{Sr} /{ }^{86} \mathrm{Sr}\right.$ initial ratio of 0.7084; Medeiros 1999). It consists of hypersthenegabbro, quartz-diorite and quartz-monzodiorite as 


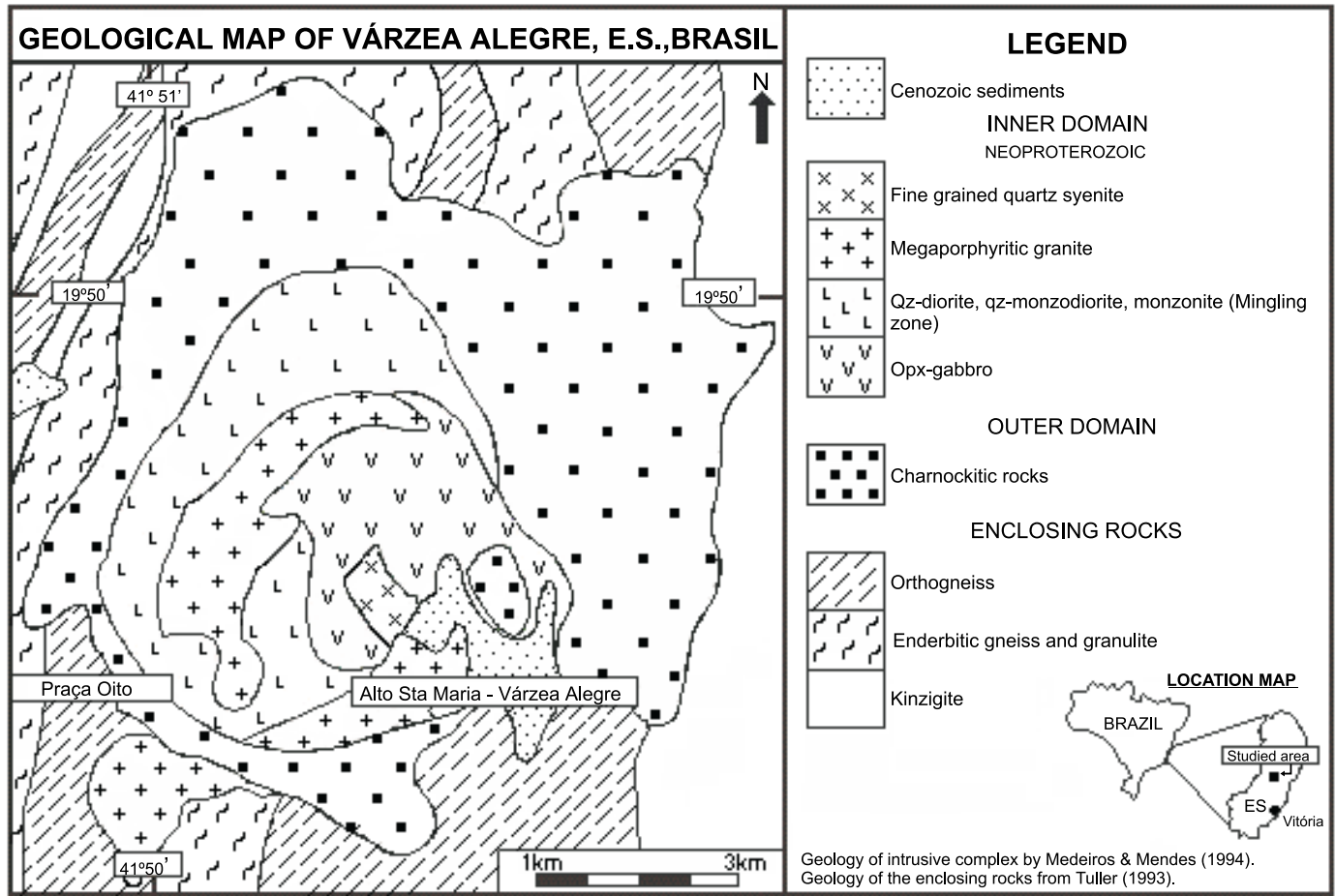

Fig. 1 - Geological map of the Varzea Alegre Intrusive Complex.

well as coarse-grained megaporphiritic granite and a small body of sphene-quartz-syenite.

The different lithotypes are disposed in a nearly circular structure with a more basic core and a more acidic to intermediate margin (Fig. 1). Several discontinuous rings of predominantly granitic composition interfinger with mainly dioritic portions. Locally sharp contacts between granitic and more basic magmas of dioritic composition are well exposed. A gradational zone of lobate masses of quartz-diorite in the megaporphyritic granite (Plate 1) is characteristic for the contact between the mingled members (felsic and mafic domains). Isolated lobate masses forming separate microgranular enclaves are rare. In such contact zones, mantled feldspars (most of the rapakivi type) as well as biotite mantled quartz were frequently observed. Large amounts of angular enclaves of gabbroic rocks in the granitic domains and the sharp contacts between gabbro and granite are field evidence of the precocious intrusion of the gabbroic magma in the beginning of the second magmatic pulse. This is a main difference between the VAIC and the Santa Angélica Intrusive Complex, further to the south (Bayer et al. 1987; Schmidt-Thomé \& Weber-Diefenbach 1987), where field evidence of mingling between gabbro and granite was well documented. In the VAIC field evidence points towards a coeval intrusion of both diorite and megaporphyritic granite, however with limited interaction between them, forming the above described restricted contact zones.

In the final stage, a fine grained sphene-bearing syenite cut all previous magmatic pulses. Several pegmatitic bodies also intruded in a late magmatic stage. They are little differentiated and carry gemstones: mainly aquamarine, turmaline and amethyst. Due to the restricted occurrence in the area of both sphene syenite and pegmatites, they will not be fur- 

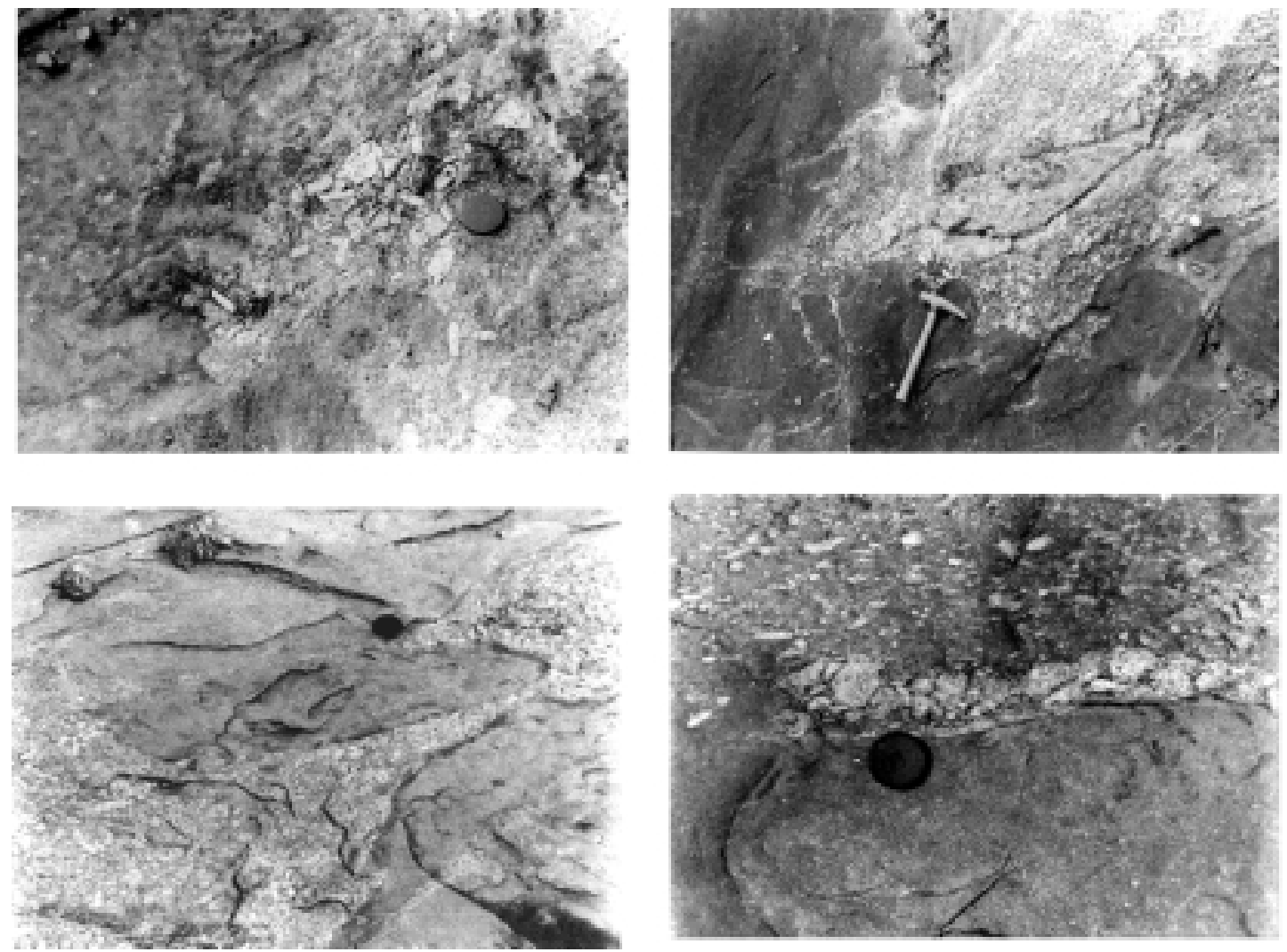

Plate 1 - Contact between felsic and mafic domains forming a gradual zone, where granitic schlieren surround dioritic lobate mass.

ther discussed in this work.

\section{WHOLE ROCK GEOCHEMISTRY}

Silica contents range from $47 \%$ in the quartzmonzogabbros of the core to $72 \%$ in the coarse grained granites of the border region (Table I-A and I-B). The restricted degree of mingling among the more basic and the more acidic magmas is indicated by clear compositional gaps in the Harker (Figs. 2-A and 2-B) and AFM diagrams, Figure 3. The variation in $\mathrm{FeO}, \mathrm{MgO}$ and $\mathrm{TiO}_{2}$ contents suggest a primary tholeiitic affinity for the hypersthene-gabbro. This lithotype is enriched in incompatible elements like $\mathrm{Ba}, \mathrm{Sr}, \mathrm{La}, \mathrm{Ce}$ and $\mathrm{Pb}$ (Figs. 4 and 5) when compared to N-MORB values. High Sr-contents in the more basic rocks contrast with the normally low values obtained for gabbros from the tholeiitic series, studied in this region (Wiedemann et al. 1995, Ludka et al. 1998). Due to limited mixing with granitic melts the primary magma evolves to a medium-K calc-alkalic suite. Ba is highly enriched mainly in the granitic rocks (Fig. 6). This is probably controlled by the replacement of $\mathrm{Ca}$ by $\mathrm{Sr}$ under high temperatures (over $800^{\circ} \mathrm{C}$ ), in the more basic plagioclases and the replacement of $\mathrm{K}$ by $\mathrm{Ba}$ in the alkali feldspars from the acidic lithotypes. This geochemical crossover could be explained by the variation in the different distributions coefficients of all elements involved in this process, with respect to the increase in temperature (Lagache 1983).

The HFS-elements are slightly depleted with values comparable to the N-MORB (Fig. 4). Nb and Ta show negative anomalies, typical for mantle 
TABLE I-A

Chemical compositions of Opx-gabbro (gab), qtz-diorite (qzdr) and qtz-monzodiorite (qzmdr) from Várzea Alegre.

\begin{tabular}{|c|c|c|c|c|c|c|c|c|}
\hline Sample & $\begin{array}{r}\text { VA-175 } \\
\text { qzmdr }\end{array}$ & $\begin{array}{r}\text { VA-34 } \\
\text { gab }\end{array}$ & $\begin{array}{r}\text { VA-162 } \\
\text { gab }\end{array}$ & $\begin{array}{r}\text { VA-10 } \\
\text { gab }\end{array}$ & $\begin{array}{r}\text { VA-109 } \\
\text { qzmdr }\end{array}$ & $\begin{array}{l}\text { VA-18 } \\
\text { qzmdr }\end{array}$ & $\begin{array}{r}\text { VA-06 } \\
\text { qzdr }\end{array}$ & $\begin{array}{r}\text { VA-20 } \\
\text { qzdr }\end{array}$ \\
\hline $\mathrm{SiO}_{2}$ & 47.21 & 47.57 & 50.84 & 50.92 & 51.54 & 52.64 & 52.83 & 52.89 \\
\hline $\mathrm{TiO}_{2}$ & 3.21 & 2.95 & 1.51 & 2.14 & 2.81 & 2.30 & 2.57 & 1.98 \\
\hline $\mathrm{Al}_{2} \mathrm{O}_{3}$ & 14.85 & 19.14 & 17.95 & 16.25 & 15.13 & 15.66 & 14.83 & 15.93 \\
\hline $\mathrm{Fe}_{2} \mathrm{O}_{3}$ & 14.19 & 11.16 & 9.06 & 10.41 & 12.47 & 10.13 & 10.77 & 9.61 \\
\hline $\mathrm{MnO}$ & 0.18 & 0.15 & 0.13 & 0.16 & 0.21 & 0.14 & 0.15 & 0.13 \\
\hline $\mathrm{MgO}$ & 4.28 & 3.94 & 6.30 & 5.31 & 3.30 & 4.20 & 3.85 & 4.25 \\
\hline $\mathrm{CaO}$ & 7.77 & 10.06 & 8.36 & 8.00 & 7.37 & 7.24 & 7.06 & 6.51 \\
\hline $\mathrm{Na}_{2} \mathrm{O}$ & 2.37 & 3.17 & 2.88 & 2.94 & 3.01 & 3.10 & 2.91 & 3.23 \\
\hline $\mathrm{K}_{2} \mathrm{O}$ & 1.92 & 0.77 & 1.30 & 1.72 & 2.26 & 2.37 & 2.35 & 2.60 \\
\hline $\mathrm{P}_{2} \mathrm{O}_{5}$ & 1.98 & 1.38 & 0.70 & 0.86 & 1.05 & 1.01 & 1.13 & 0.71 \\
\hline LOI & 1.80 & 0.48 & 0.54 & 0.49 & 0.30 & 0.72 & 0.61 & 0.96 \\
\hline Total & 99.76 & 100.77 & 99.57 & 99.20 & 99.45 & 99.51 & 99.06 & 98.80 \\
\hline $\mathrm{Sc}$ & 22 & 21 & 19 & 22 & 25 & 21 & 22 & 17 \\
\hline Co & 63 & 93 & 63 & 56 & 57 & 60 & 72 & 60 \\
\hline $\mathrm{Ni}$ & $<10$ & 13 & 46 & 35 & 11 & 25 & 25 & 28 \\
\hline V & 357 & 284 & 157 & 199 & 210 & 195 & 232 & 163 \\
\hline $\mathrm{Cu}$ & 29 & 31 & 23 & 27 & 24 & 28 & 30 & 23 \\
\hline $\mathrm{Zn}$ & n.d. & 115 & 102 & 123 & 170 & 127 & 142 & 116 \\
\hline $\mathrm{Rb}$ & 47 & $<6$ & 27 & 45 & 60 & 49 & 52 & 76 \\
\hline $\mathrm{Ba}$ & 1596 & 720 & 1091 & 320 & 1717 & 1841 & 1826 & 1174 \\
\hline $\mathrm{Sr}$ & 870 & 1189 & 1393 & 1003 & 970 & 1040 & 891 & 808 \\
\hline $\mathrm{Ga}$ & 26 & 23 & 20 & 21 & 25 & 22 & 21 & 21 \\
\hline $\mathrm{Pb}$ & 20 & 8 & 13 & 20 & 21 & 19 & 20 & 16 \\
\hline Cs & 1 & 0.36 & n.d & 0.88 & 1.24 & n.d & 0.51 & 2.16 \\
\hline $\mathrm{Y}$ & 42.78 & 26.30 & 18.30 & 32.85 & 47.24 & 32.81 & 36.23 & 30.78 \\
\hline $\mathrm{Nb}$ & 23.75 & 19.75 & 10.44 & 22.58 & 34.02 & 24.13 & 27.46 & 24.43 \\
\hline $\mathrm{Zr}$ & 315.91 & 96.34 & 108.64 & 292.26 & 340.66 & 339.68 & 368.26 & 266.68 \\
\hline Hf & 8.07 & 2.69 & 2.55 & 8.30 & 9.76 & 9.41 & 10.00 & 6.87 \\
\hline $\mathrm{Ta}$ & 1.90 & 1.63 & 0.86 & 1.42 & 2.32 & 1.64 & 1.96 & 1.85 \\
\hline $\mathrm{Th}$ & 6.88 & 1.08 & 4.10 & 7.11 & 6.16 & 9.41 & 9.09 & 9.83 \\
\hline
\end{tabular}

Obs: Major and some trace elements by X-ray fluorescence; HFSE by INAA and/or ICP.

derived magmas contaminated by crustal contributions (Sun \& McDonough 1989). Positive anomalies of $\mathrm{Sm}$ and $\mathrm{Eu}$, diluted in the REE diagram (Fig. 5) due to the normalization with the chondrite, indicate crystallization under low $\mathrm{O}_{2}$-fugacity condi- tions. The REE patterns of the medium-K calcalkalic series are similar to those of magmatites from anomalous segments of the midoceanic ridges and basanites, probably originated from a previously enriched mantle (Frey 1984). 


\section{TABLE I-B}

Chemical compositions of charnoenderbitic (charn) rocks, qtz-syenite (qzsye) and megaporphyritic granite (mggr) from Várzea Alegre.

\begin{tabular}{|c|c|c|c|c|c|c|c|c|c|c|c|}
\hline Sample & $\begin{array}{r}\text { VA-90 } \\
\text { charn } \\
\end{array}$ & $\begin{array}{r}\text { VA-125 } \\
\text { charn } \\
\end{array}$ & $\begin{array}{r}\text { VA-16a } \\
\text { charn } \\
\end{array}$ & $\begin{array}{r}\text { VA-64 } \\
\text { qzsye }\end{array}$ & $\begin{array}{r}\text { VA-47 } \\
\text { qzsye } \\
\end{array}$ & $\begin{array}{r}\text { VA-164 } \\
\text { charn } \\
\end{array}$ & $\begin{array}{r}\text { VA-163 } \\
\text { qzsye } \\
\end{array}$ & $\begin{array}{r}\text { VA-42 } \\
\text { charn } \\
\end{array}$ & $\begin{array}{r}\text { VA-124 } \\
\text { mggr } \\
\end{array}$ & $\begin{array}{r}\text { VA-109 } \\
\text { mggr }\end{array}$ & $\begin{array}{r}\text { VA-176 } \\
\text { mggr } \\
\end{array}$ \\
\hline $\mathrm{SiO}_{2}$ & 58.66 & 60.05 & 61.89 & 62.11 & 63.80 & 63.84 & 64.52 & 64.90 & 68.48 & 71.36 & 71.49 \\
\hline $\mathrm{TiO}_{2}$ & 1.47 & 1.01 & 1.11 & 1.26 & 0.99 & 0.74 & 1.05 & 0.86 & 0.67 & 0.35 & 0.30 \\
\hline $\mathrm{Al}_{2} \mathrm{O}_{3}$ & 16.00 & 17.17 & 17.13 & 15.25 & 15.26 & 16.49 & 15.46 & 15.78 & 14.71 & 13.88 & 14.69 \\
\hline $\mathrm{Fe}_{2} \mathrm{O}_{3}$ & 8.44 & 6.36 & 6.99 & 5.25 & 4.31 & 5.09 & 4.54 & 5.24 & 4.04 & 2.12 & 2.35 \\
\hline $\mathrm{MnO}$ & 0.15 & 0.12 & 0.12 & 0.04 & 0.05 & 0.08 & 0.05 & 0.12 & 0.07 & 0.02 & 0.03 \\
\hline $\mathrm{MgO}$ & 1.92 & 1.18 & 1.40 & 1.44 & 1.18 & 0.78 & 1.32 & 1.00 & 0.76 & 0.43 & 0.32 \\
\hline $\mathrm{CaO}$ & 4.54 & 4.02 & 4.54 & 3.14 & 2.63 & 3.82 & 2.78 & 3.76 & 1.88 & 1.53 & 1.40 \\
\hline $\mathrm{Na}_{2} \mathrm{O}$ & 3.44 & 3.84 & 3.60 & 3.12 & 2.57 & 3.53 & 2.77 & 3.45 & 3.19 & 3.05 & 3.16 \\
\hline $\mathrm{K}_{2} \mathrm{O}$ & 3.35 & 4.29 & 3.31 & 5.14 & 5.73 & 3.99 & 5.55 & 3.57 & 4.74 & 5.41 & 6.05 \\
\hline $\mathrm{P}_{2} \mathrm{O}_{5}$ & 0.68 & 0.43 & 0.46 & 0.41 & 0.37 & 0.31 & 0.40 & 0.46 & 0.40 & 0.16 & 0.15 \\
\hline LOI & 0.47 & 0.54 & 0.83 & 0.99 & 1.17 & 0.56 & 1.46 & 0.94 & 0.79 & 0.44 & 0.42 \\
\hline Total & 99.12 & 98.65 & 101.38 & 98.15 & 98.06 & 99.23 & 99.90 & 100.08 & 99.73 & 98.75 & 100.36 \\
\hline $\mathrm{Sc}$ & 17 & 14 & 16 & $<8$ & $<8$ & 13 & $<8$ & 14 & $<8$ & $<8$ & $<8$ \\
\hline Co & 61 & 63 & 69 & 53 & 54 & 49 & 48 & 56 & 69 & 57 & 42 \\
\hline $\mathrm{Ni}$ & 14 & 12 & 12 & 11 & 11 & $<10$ & $<10$ & 11 & $<10$ & $<10$ & 10 \\
\hline V & 124 & 67 & 57 & 72 & 48 & 30 & 69 & 35 & 32 & $<15$ & $<15$ \\
\hline $\mathrm{Cu}$ & 19 & 15 & 16 & 19 & 12 & 10 & 13 & 11 & $<10$ & $<10$ & $<10$ \\
\hline $\mathrm{Zn}$ & 13 & 126 & 130 & 136 & 96 & 98 & 93 & 101 & 86 & 38 & n.d. \\
\hline $\mathrm{Rb}$ & 64 & 91 & 72 & 174 & 196 & 82 & 184 & 79 & 212 & 141 & 229 \\
\hline $\mathrm{Ba}$ & 2727 & 3043 & 2594 & 3223 & 2207 & 2593 & 1836 & 2246 & 1613 & 1074 & 771 \\
\hline $\mathrm{Sr}$ & 579 & 518 & 534 & 618 & 393 & 458 & 341 & 428 & 280 & 206 & 147 \\
\hline $\mathrm{Ga}$ & 22 & 23 & 22 & 21 & 20 & 23 & 19 & 20 & 22 & 18 & 22 \\
\hline $\mathrm{Pb}$ & 21 & 24 & 19 & 31 & 29 & 23 & 24 & 22 & 25 & 39 & 43 \\
\hline Cs & n.d & 0.90 & 1.27 & 0.35 & 0.35 & 1.46 & 0.46 & 1.14 & 3.21 & 1.02 & 4.02 \\
\hline Y & 35.86 & 31.77 & 31.90 & 28.41 & 18.12 & 26.33 & 15.18 & 28.56 & 47.53 & 13.99 & 39.16 \\
\hline $\mathrm{Nb}$ & 35.23 & 33.15 & 33.36 & 40.09 & 21.02 & 27.96 & $?$ & 36.18 & 33.04 & 7.15 & 25.43 \\
\hline $\mathrm{Zr}$ & 724.49 & 915.24 & 859.81 & 953.55 & 650.69 & 642.12 & 650.70 & 818.55 & 359.04 & 197.05 & 224.34 \\
\hline $\mathrm{Hf}$ & 18.30 & 22.90 & 21.80 & 23.90 & 18.90 & 17.10 & 18.20 & 22.30 & 10.60 & 7.12 & 7.57 \\
\hline $\mathrm{Ta}$ & 2.27 & 2.23 & 2.37 & 3.01 & 1.64 & 1.93 & 1.04 & 2.47 & 2.39 & 1.14 & 1.86 \\
\hline Th & 2.41 & 4.63 & 6.14 & 18.70 & 42.40 & 2.50 & 21.90 & 3.73 & 2.17 & 29.70 & 35.70 \\
\hline
\end{tabular}

Obs: Major and some trace elements by X-ray fluorescence; HFSE by INAA and/or ICP.

The megaporphyritic granite shows a geochemical behavior (Fig. 6) compatible with those of other plutonites from the high-K calc-alkalic suites defined by Wiedemann (1993) from the region of Espírito Santo. The REE-patterns of the granites from the VAIC (Fig. 7) are however less fractionated and the total amount of HREE is higher.

The progressive increase of the REE-contents from the gabbroic to the dioritic rocks (Fig. 5), without Eu-anomalies suggests the predominance of a weakly process of fractional crystallization of a restricted magmatic series. The fractional crystallization involving simultaneously olivine, plagioclase, clinopyroxene and magnetite increases the total amount of REE in the gabbros and diorites, without however causing any significant interelement fractionation. In this way the characteristic pattern of the primary magma is maintained together with 

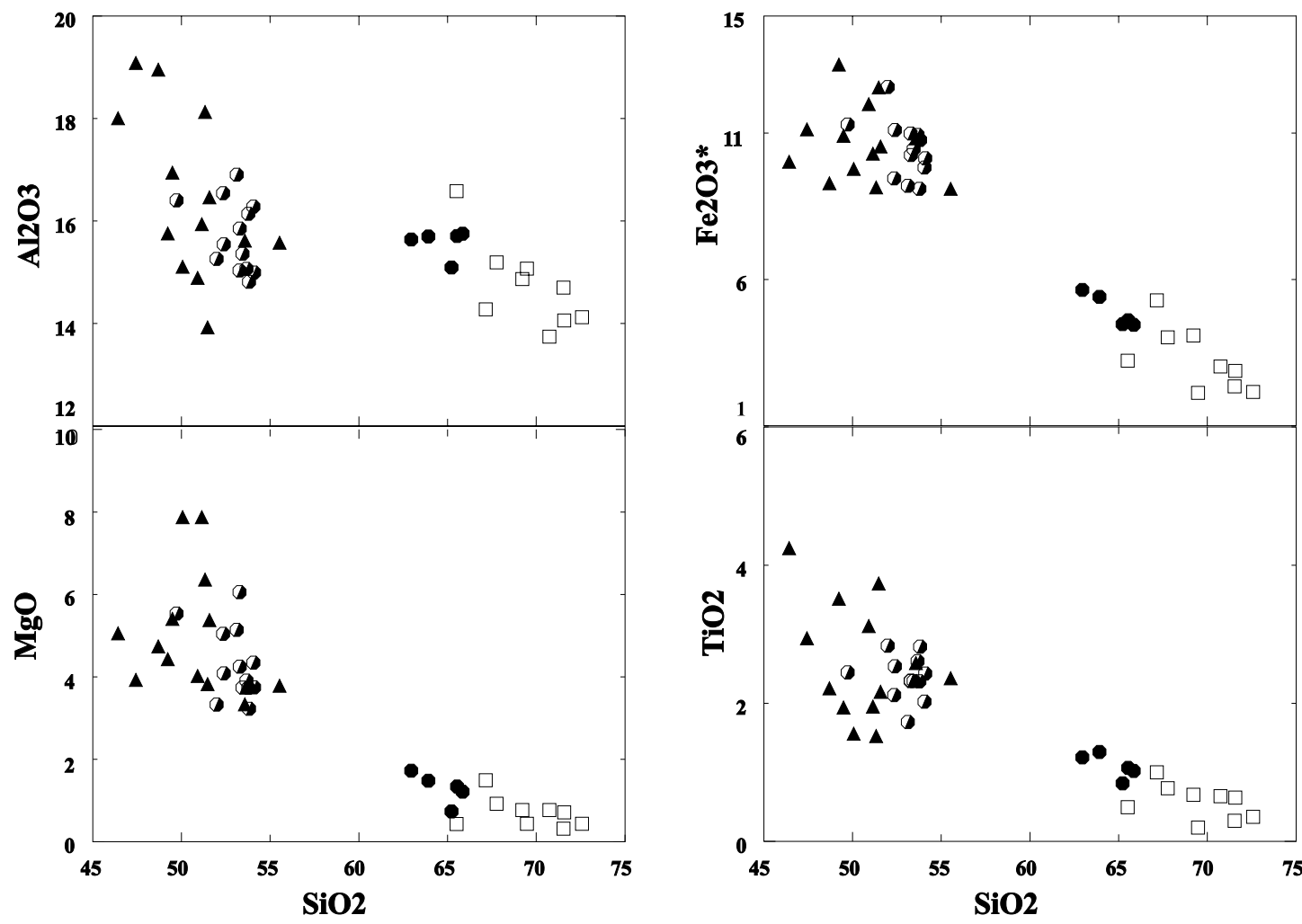

Fig. 2a - Harker diagramas for the rocks of the VAIC. Symbols: $\boldsymbol{\Delta}$ Opx-gabbro; qz-diorites to qz-monzodiorites;

- sphene qz-syenite; $\square$ megagaporphyritic granite.

the simultaneous relative increase of the REE. The normalization diagrams on Figures 5 and 7 show clear differences in the behavior of the HFSelements from diorites/gabbros in comparison to the megaporphyritic granite. The behaviour of major and trace elements points towards a clearly independent evolution in comparison to the medium-K calc alkalic series that originated the gabbroic and dioritic rocks. The similarities in the REE-patterns however are certainly due to magma commingling and mixing.

In the charnoenderbitic rocks of the outer rim the variation of the silica content is restricted to a range from 59 to 65\% (Mendes et al. 1997, Mendes et al. 1999). According to these works, the charnoenderbitic rocks of the outer domain are high-K calc-alkalic enriched in LIL and HFS elements. Zr and $\mathrm{P}_{2} \mathrm{O}_{5}$ saturation levels of the Várzea Alegre charnoenderbites indicate magmatic crystallization temperatures around $950^{\circ} \mathrm{C}$. Estimated crystallization pressure range from 6.5 to $7 \mathrm{~Kb}$.

The spidergram of Figure 8 reveals geochemical differences between this older unit and the younger gabbro/dioritic-granitic unit. The REEpatterns for the charnoenderbites (Fig. 9) however are similar to those of the gabbros and diorites. Nevertheless the absence of an evolution to negative $\mathrm{Eu}-$ anomalies, as observed in the granite of Figure 7, is consistent with the lack of consanguinity between the magmas that formed the outer and the inner rims of the VAIC. The stronger argument is nonetheless the geochronological data that shows a gap around 25 Ma between the two magmatic pulses (535-520 $\mathrm{Ma}-\mathrm{U}-\mathrm{Pb}$ in zircons ( Bilal et al. 1998) for the 

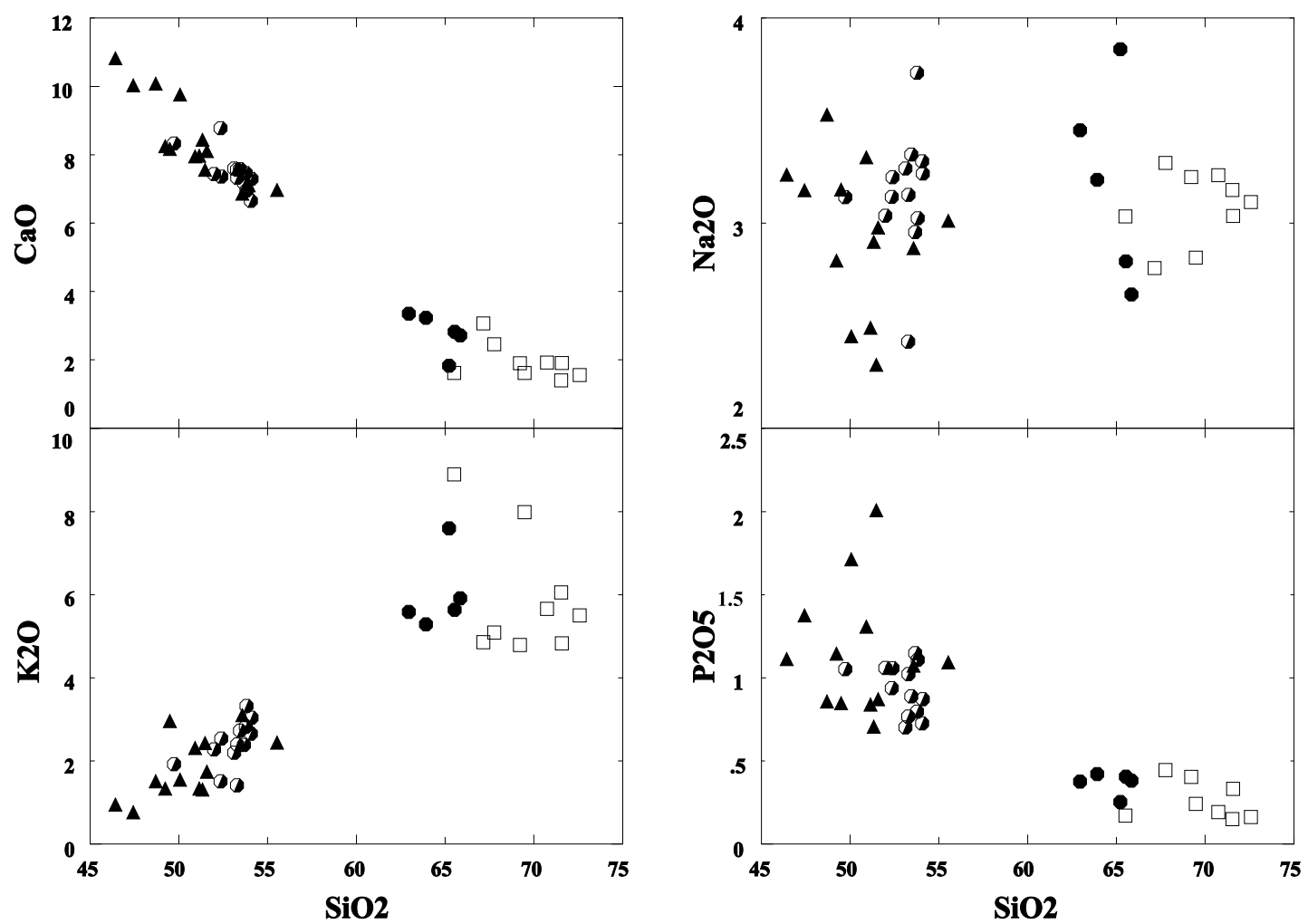

Fig. 2b-Harker diagramas for the rocks of the VAIC. Symbols: $\boldsymbol{\Delta}$ Opx-gabbro; qz-diorites to qz-monzodiorites; sphene qz-syenite; $\square$ megagaporphyritic granite.

charnoenderbite and $508 \pm 12 \mathrm{Ma}$. for the granite).

\section{PETROGRAPHY AND MINERAL CHEMISTRY}

Fifty five (55) thin sections of different intrusive rocks of the VAIC, excluding the charnockitic rim, were studied in detail. The major mineral phases of OPX-gabbros to quartz-diorites and one hibrid monzogranite (a total of 7 thin sections) were analyzed under a 4 WDS-channels Jeol Microprobe with a fifth EDS-channel. The results are presented in tables III to VII. Modal analysis of 33 samples (1000 points/section) indicate a monzonitic or high$\mathrm{K}$ calc-alkalic trend in the QAP-diagram (Fig. 10). Intermediary compositions are lacking, highlighting the slight interaction or mixing between the contrasting members.

OPX (hypersthene)-CPX (augite)-gabbros, mostly with intergranular textures, may grade locally from glomeroporphyritic to granular textures. Plagioclase, up to $6 \mathrm{~mm}$ in size, is the most abundant phase. They tend to be aligned indicating a clear magmatic foliation. When quartz is present, it is found between crossed plagioclase slabs or as vermicular masses in fractures. Widespread signs of spongy cellular intergrowths of plagioclase/biotite, $\mathrm{CPX} /$ hornblende and hornblende/ilmeno-magnetite suggest dissolution (and/or direct melting) of one phase and solidification of the other, as mingling of contrasting magmas occurred (Hibbard 1995). In previous works such petrographic features have been interpreted as symplectites pointing towards a reequilibrium in the sub-solidus state (Wiedemann et al. 1992).

Mantled pyroxenes can be surrounded by magnesio- to tschermakitic-hornblende, grading to 


\section{TABLE II-A}

REE compositions of Opx-gabbro (gab), qtz-diorite (qzdr) and qtz-monzodiorite (qzmdr) from Várzea Alegre.

\begin{tabular}{l|rrrrrrrr}
\hline Sample & $\begin{array}{r}\text { VA-175 } \\
\text { qzmdr }\end{array}$ & $\begin{array}{r}\text { VA-34 } \\
\text { gab }\end{array}$ & $\begin{array}{r}\text { VA-162 } \\
\text { gab }\end{array}$ & $\begin{array}{r}\text { VA-10 } \\
\text { gab }\end{array}$ & $\begin{array}{r}\text { VA-109 } \\
\text { qzmdr }\end{array}$ & $\begin{array}{r}\text { VA-18 } \\
\text { qzmdr }\end{array}$ & $\begin{array}{r}\text { VA-06 } \\
\text { qzdr }\end{array}$ & $\begin{array}{r}\text { VA-20 } \\
\text { qzdr }\end{array}$ \\
\hline $\mathrm{La}$ & 110 & 51.30 & 44.20 & 73.20 & 106 & 103 & 106 & 68.40 \\
$\mathrm{Ce}$ & 247 & 117.00 & 89.40 & 158.00 & 217.00 & 212.00 & 220.00 & 135.00 \\
$\mathrm{Nd}$ & 107 & 55.20 & 38.60 & 65.50 & 96.00 & 85.00 & 96.00 & 63.90 \\
$\mathrm{Sm}$ & 20.30 & 10.80 & 7.42 & 13.40 & 18.90 & 15.20 & 17.20 & 12.20 \\
$\mathrm{Eu}$ & 5.27 & 3.75 & 2.65 & 3.67 & 5.36 & 4.10 & 4.56 & 3.23 \\
$\mathrm{~Tb}$ & 1.77 & 0.97 & 0.59 & 1.18 & 1.83 & 1.26 & 1.48 & 1.01 \\
$\mathrm{Yb}$ & 2.76 & 1.49 & 1.17 & 2.27 & 3.26 & 2.37 & 2.44 & 2.02 \\
$\mathrm{Lu}$ & 0.45 & 0.21 & 0.21 & 0.31 & 0.49 & 0.39 & 0.30 & 0.34 \\
\hline
\end{tabular}

Obs: REE by INAA and / or ICP.

\section{TABLE II-B}

REE compositions of charnoenderbitic (charn) rocks, qtz-syenite (qzsye) and megaporphyritic granite (mggr) from Várzea Alegre.

\begin{tabular}{l|rrrrrrrrrrr}
\hline Sample & $\begin{array}{r}\text { VA-90 } \\
\text { charn }\end{array}$ & $\begin{array}{r}\text { VA-125 } \\
\text { charn }\end{array}$ & $\begin{array}{r}\text { VA-16a } \\
\text { charn }\end{array}$ & $\begin{array}{r}\text { VA-64 } \\
\text { qzsye }\end{array}$ & $\begin{array}{r}\text { VA-47 } \\
\text { qzsye }\end{array}$ & $\begin{array}{r}\text { VA-164 } \\
\text { charn }\end{array}$ & $\begin{array}{r}\text { VA-163 } \\
\text { qzsien }\end{array}$ & $\begin{array}{r}\text { VA-42 } \\
\text { charn }\end{array}$ & $\begin{array}{r}\text { VA-124 } \\
\text { mggr }\end{array}$ & $\begin{array}{r}\text { VA-109 } \\
\text { mggr }\end{array}$ & $\begin{array}{r}\text { VA-176 } \\
\text { mggr }\end{array}$ \\
\hline $\mathrm{La}$ & 76.40 & 70.70 & 80.40 & 224.00 & 230.00 & 42.70 & 183.00 & 55.60 & 38.60 & 89.90 & 113.00 \\
$\mathrm{Ce}$ & 155.00 & 144.00 & 156.00 & 485.00 & 479.00 & 94.10 & 374.00 & 111.00 & 85.80 & 171.00 & 242.00 \\
$\mathrm{Nd}$ & 72.00 & 64.20 & 67.70 & 165.00 & 145.00 & 45.20 & 114.00 & 51.00 & 43.00 & 56.80 & 96.00 \\
$\mathrm{Sm}$ & 13.20 & 12.20 & 13.00 & 25.60 & 19.40 & 9.83 & 14.90 & 10.90 & 9.62 & 9.05 & 17.60 \\
$\mathrm{Eu}$ & 4.84 & 5.24 & 5.17 & 4.52 & 3.05 & 4.98 & 2.37 & 4.75 & 2.40 & 2.04 & 1.77 \\
$\mathrm{~Tb}$ & 1.24 & 1.11 & 1.11 & 1.38 & 0.79 & 0.94 & 0.72 & 0.98 & 1.36 & 0.68 & 1.60 \\
$\mathrm{Yb}$ & 2.52 & 2.14 & 2.43 & 1.46 & 1.24 & 2.11 & 0.69 & 2.19 & 3.58 & 0.94 & 2.72 \\
$\mathrm{Lu}$ & 0.41 & 0.35 & 0.41 & 0.19 & 0.15 & 0.33 & 0.11 & 0.30 & 0.53 & 0.14 & 0.36 \\
\hline
\end{tabular}

Obs: REE by INAA and/or ICP.

edenitic and Fe-edenitic compositions (Fig. 11). Elongated eyeshaped exsolution lamellae of CPX in OPX as well as of OPX in CPX are common features. They are mostly parallel to the (100) planes (Fig. 12). OPX is normally the first mafic mineral to crystallize. It is predominately euhedral and can be mantled or replaced by CPX. Blades of biotite replace plagioclase in the contact to CPX. In this case, newly formed quartz is the sub-product of this replacement. The orthopyroxenes (OPX) grade in composition from hypersthene, in the gabbroic rocks, to Fe-hypersthene, in the quartz-dioritic lithotypes (Fig. 13). They are usually strongly pleochroic, from pink to pale reddish brown along $a$ and clearly green along $b$. The clinopyroxenes (CPX) grade in composition from salite, in the gabbroic rocks to augite, in the quartz-diorites. They are not pleochroic, show light green colors and are usually subhedral (Figs. 14 and 15).

The presence of plagioclase with undulated extinction, curved secondary polysynthetic twins and fractures as well as the presence of augite and apatite with kink bands strongly suggests that these phases were already solid before the mingling of the con- 


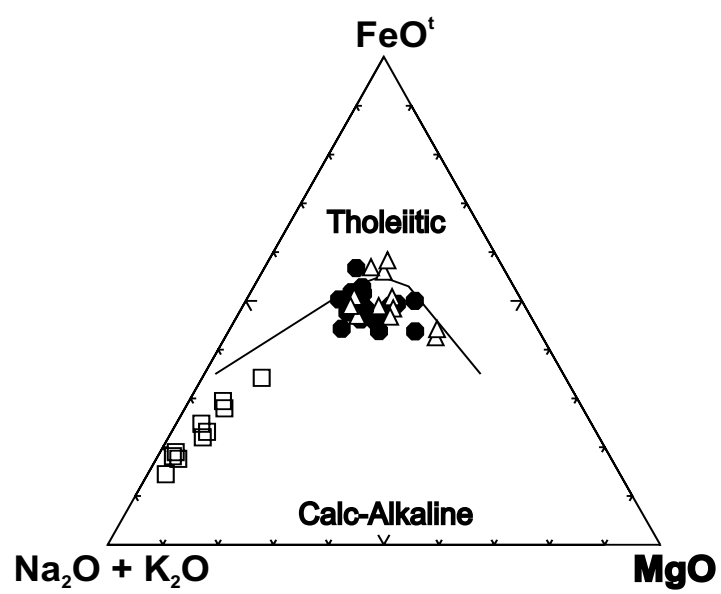

Fig. 3 - AFM-diagram showing a calc-alkalic trend with clear compositional gap. Some basic samples plot in the tholeiitic field. Symbols: $\Delta$ Opx-gabbro; qz-diorites to qz-monzodiorites; $\square$ megagaporphyritic granite.

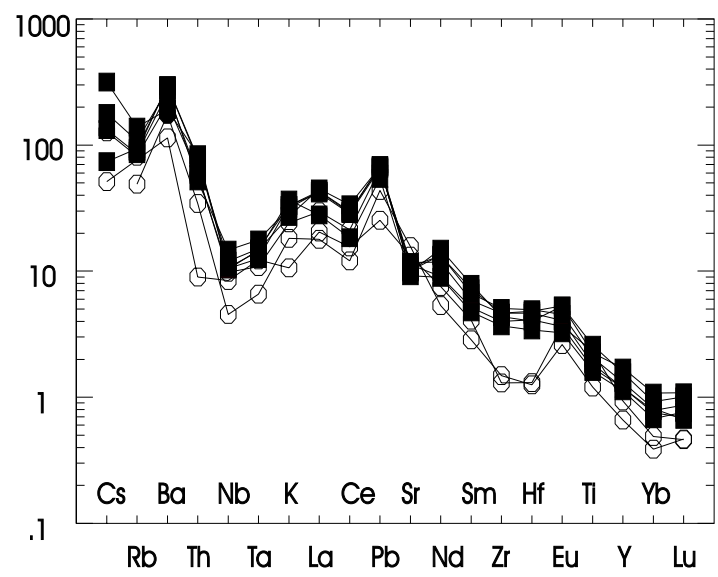

Fig. 4 - Spidergram of compatible and incompatible elements of qz-diorites, qz-monzodiorites $(\mathbf{\square})$ and OPX-gabbros $(\mathrm{O})$. NMORB-normalization after Sun and McDonough (1989). Explanation in text.

trasting crystal mushes (Figs. 14 and 15). The local stirring of the mushes may have caused the observed signs of recrystallization and deformation.

The spongy cellular intergrowths are due to dissolution of phases during the process of mingling (syn-mingling) accompanied by a further crystallization in a post mingling stage (Hibbard 1995).

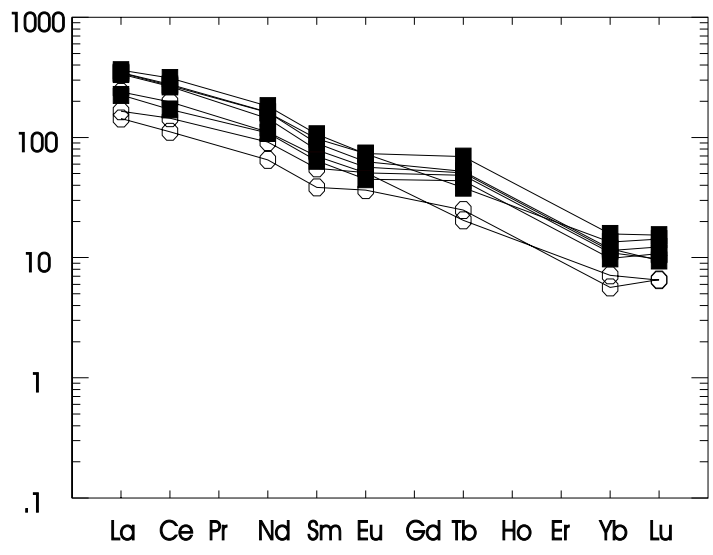

Fig. 5-REE-spectra of samples of qz-diorites, qz-monzodiorites and OPX-gabbros. Condrite-normalization after Boynton (1984). Explanation in text.

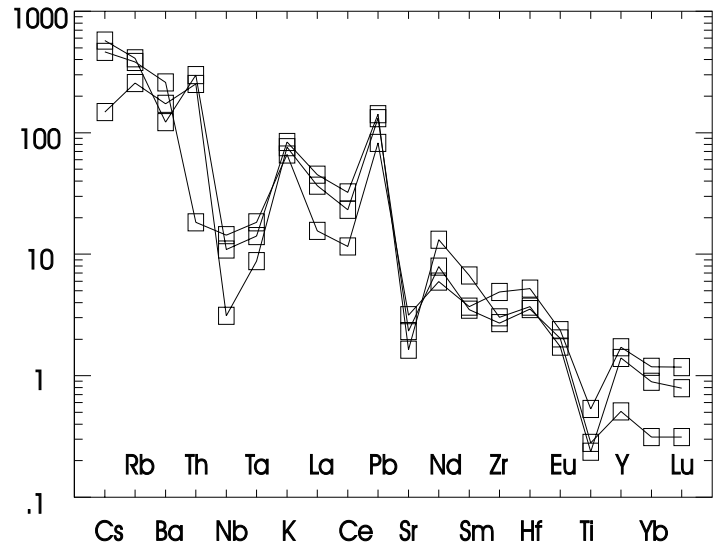

Fig. 6-Spidergram of compatible and incompatible elements of the megaporphyritic granite. N-MORB-normalization after Sun and McDonough (1989). Explanation in text.

The biotite is strongly pleochroic, dark reddish brown to light brown, rich in needles of apatite (apatite I) and may contain some subordinate ilmenite as inclusions. This suggests that biotite solidified in a late mingling stage.

In the dioritic to quartz-monzodioritic rocks the plagioclase is clear and sometimes antiperthitic. It usually shows a subhedral inequigranular fabric. Common accessory minerals are fluor-apatite and ilmeno-magnetite. Locally more evident signs of contamination with the granitic magma are present. 


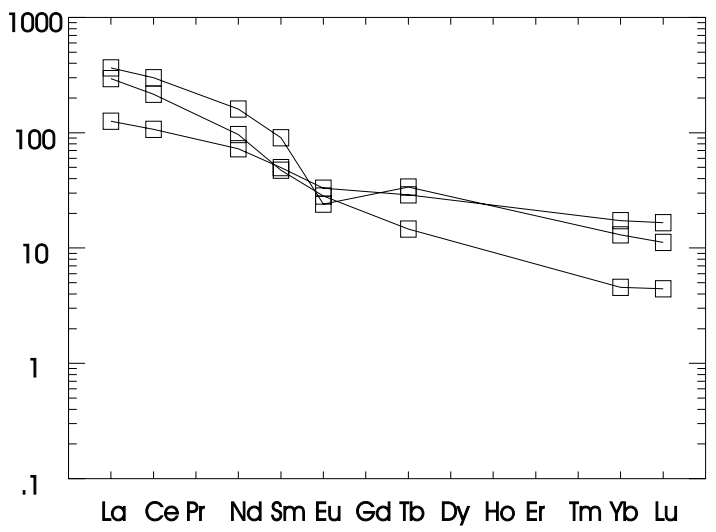

Fig. 7 - REE-spectra of samples of the megaporphyritic granite. Normalization after Boynton (1984). Explanation in text.

Closer to the granite, where these rocks become porphyritic, dusty andesine crystals, crowded with fine ilmenite and/or magnetite needles, predominate in a matrix of hypersthene, augite, hornblende, Ti-biotite and andesine. With the increase of diffusion, the feldspars become mesoperthitic and acicular apatite is more abundant. The predominant mafic mineral in this domain is hornblende, grading from tchermackitic to ferriferous pargasite. Biotite with euhedral apatite inclusions, as well as CPX and OPX may in some cases occur.

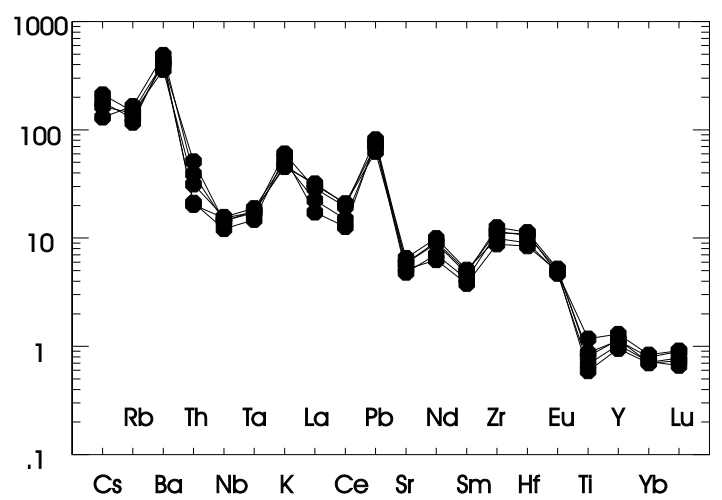

Fig. 8 - Spidergram of compatible and incompatible elements of charnoenderbites from the outer domain. N-MORBnormalization after Sun and McDonough (1989). Explanation in text.

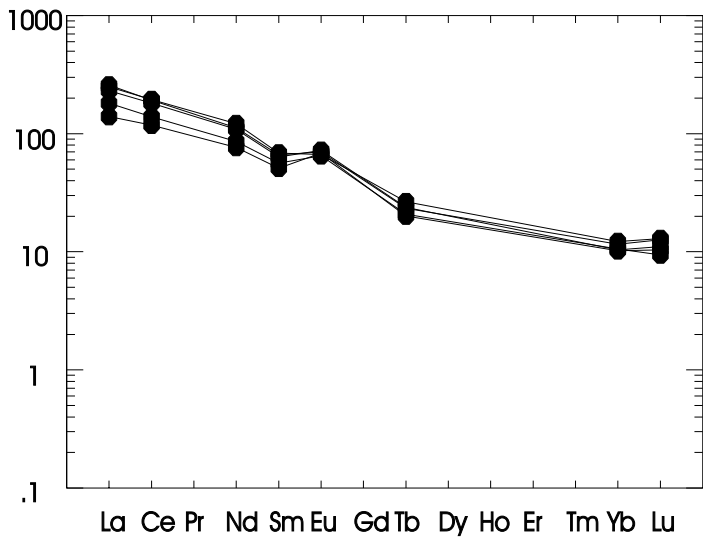

Fig. 9 - REE-spectra of samples of charnoenderbites from the outer domain. Normalization after Boynton (1984). Explanation in text.

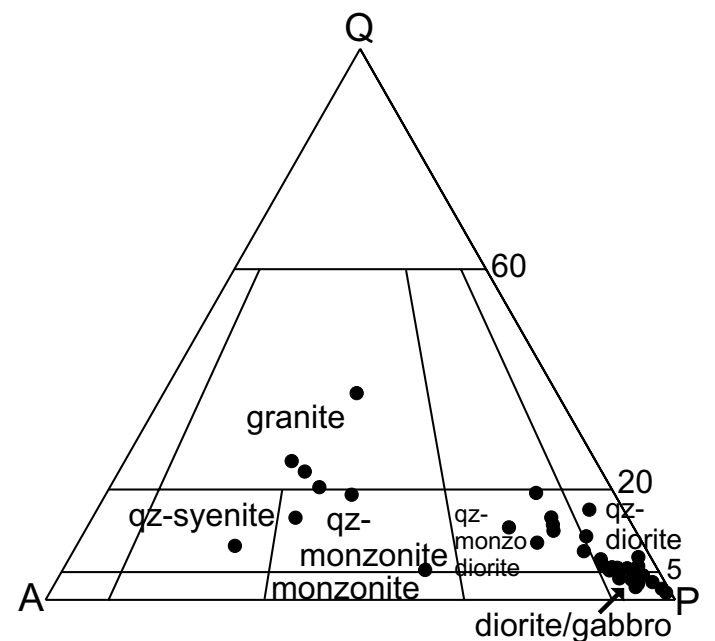

Fig. 10 - QAP-diagram showing a clear compositional gap between mafic and felsic rocks.

The common accessory minerals of these rocks are: fluorapatite, zircon, ilmenite, magnetite, epidote and sphene. The presence of acicular apatite is an evidence of the accelerated cooling rates, owing to the contact of the contrasting mushes.

The megaporphyritic granite shows a coarse grained matrix consisting of plagioclase (around $\mathrm{An}_{24}$ ), microcline, quartz and biotite. Microcline as megacrysts is usually corroded, with abundant quartz, biotite and plagioclase inclusions. Mesop- 

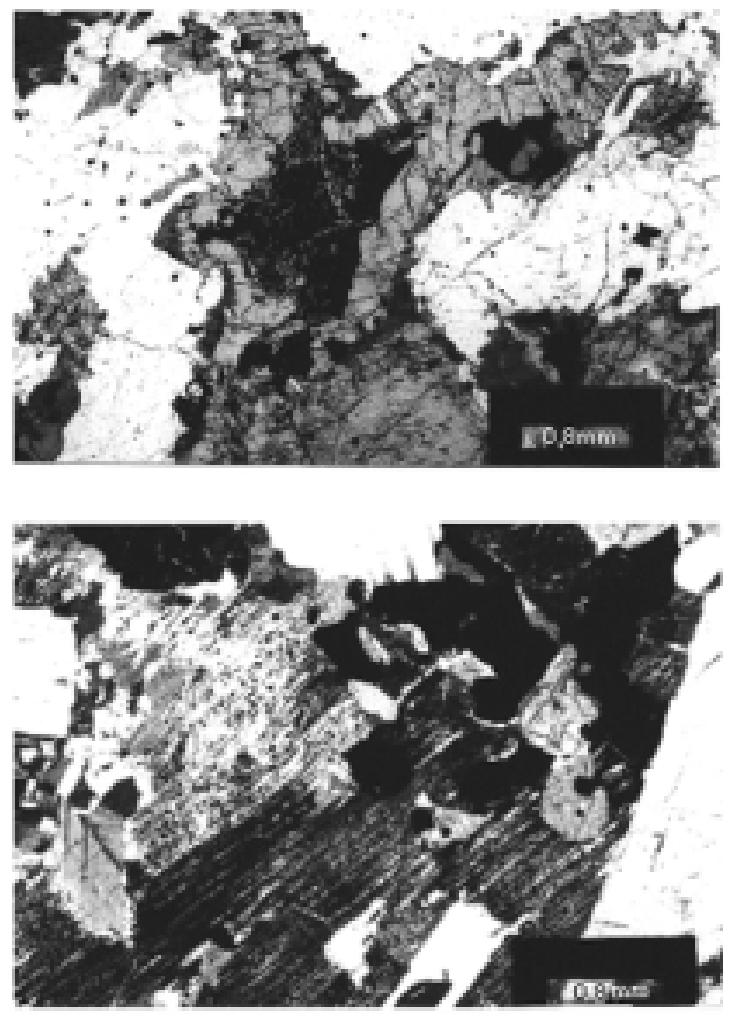

Figs. 11-12 - (Fig. 11) - Mantled pyroxenes surrounded by a corona of magnesio- to -tschermakitic- hornblende, which grades to edenitic and Fe-edenitic compositions. (Fig. 12) - Elongated eyeshaped exsolution lamellae of CPX in OPX as well as OPX in CPX parallel to the (100) planes.

erthite may be replaced in the same crystal into microcline. Zircon, sphene, epidote/allanite and apatite are normally euhedral and tend to be concentrated in the biotite-rich domains, which surround the microcline megacrysts.

Pyroxenes from the gabbroic rocks were analyzed in more detail because they may preserve, in a kind of a frozen state, the early crystallization history of the contrasting magmas. Representative analyses of CPX and OPX with no visible oxide exsolutions are given in table III and IV.

In Figure 13 the variation in composition of both CPX-grains and exsolution lamellae reveals a narrow interrupted sub-solidus tholeiitic trend ranging from $\mathrm{Wo}_{48} \mathrm{En}_{41} \mathrm{Fs}_{11}$ (salite) to $\mathrm{Wo}_{44} \mathrm{En}_{36} \mathrm{Fs}_{20}$ (augite). The composition of OPX-grains and exsolution lamellae varies from $\mathrm{W}_{01} \mathrm{En}_{59} \mathrm{Fs}_{40}$ (hypersthene) to $\mathrm{W}_{02} \mathrm{En}_{46} \mathrm{Fs}_{52}$ (Fe-hypersthene). These trends are close to the sub-solidus trend from Skaergaard CPX-crystals (Brown \& Vincent 1963, Nwe 1970). Analytical scanning of several CPX exsolution lamellae in OPX-grains and individual CPXgrains of OPX-gabbros points towards a second variation trend, from salite to sub-calcic augite. One analysis fell in the pigeonitic field. This second trend follows a tie-line of the diagram (Brown 1961). This unusual variation may indicate an abrupt change in the cooling rates. Compositional trends of pyroxenes along the tie-line are well known for volcanic rocks (Kushiro 1960, Deer et al. 1978). Such signs of abrupt changes in temperature in a deep plutonic environment are further evidence of mingling between contrasting magmas.

Both OPX- and CPX-grains generally show replacements by Ti-biotite (ca. $5 \% \quad \mathrm{TiO}_{2}-$ see table $\mathrm{VI}$ ) and by $\mathrm{Mg}$ - and edenitic hornblende. Exsolution lamellae of ilmenite, CPX and OPX, parallel to the (100) crystallographic plane are very common and indicate Ti-, Fe- and/or Ca-richer primary compositions of Bushveld-type pyroxenes (Atkins 1969) (Figs. 14 and 15).

Best and Mercy (1967) in a classic work on the composition of mafic minerals in the calc-alkalic igneous complex of Guadalupe pointed out the uniformity of coexisting Ca-rich CPX and OPX, indicating relatively high $\mathrm{f}_{\mathrm{H}_{2} \mathrm{O}}$ and low crystallization temperatures. In this work the similarity between plutonic and granulitic pyroxenes was highlighted and the term auto-metamorphism was introduced.

Burns (1985) used binary diagrams to separate the fields of typical calc-alkalic from tholeiitic pairs of coexisting plagioclase and pyroxenes (both CPX and OPX). VAIC data were compared with the several variation trends of coexisting plutonic tholeiitic pyroxenes and plagioclases, e.g. Kaerven, east Greenland, Skaergaard and Bushveld. The resulting points initially plot close to the tholeiitic 


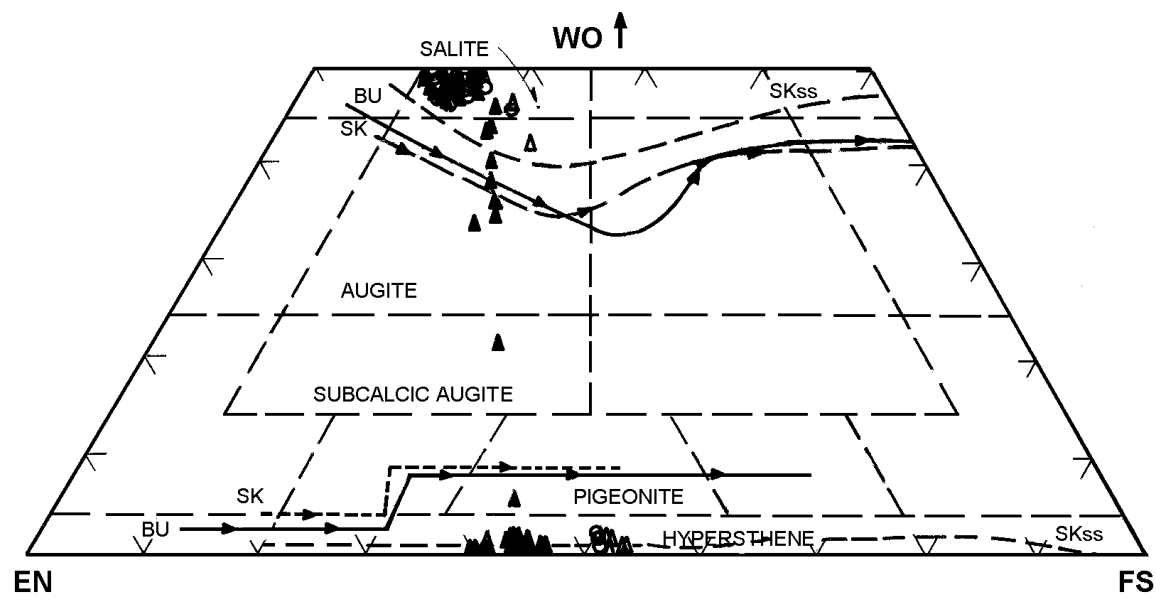

Fig. 13 - Variation of compositions from both pyroxene grains and exsolution lamellae reveals a narrow interrupted sub-solidus tholeiitic trend close to the sub-solidus trend of Skaergaard (Skss) CPX-crystals (Deer et al. 1978). A second trend varies from the salite towards the pigeonite field, along a tie-line of the diagram (see text for explanation). The analysis of OPX crystals and CPX exsolution lamellae, from the same rock sample, reveals compositions along a sub-solidus trend as well.

trends. More evolved rocks drift towards the calcalkalic field (Figs. 16 and 17), remaining however outside from the typical calc-alkalic field. This fact together with the coexistence of Ca-rich CPX and OPX suggests that the evolution of the fractional crystallization of the gabbroic magma was coeval with the beginning of mingling with the granite. This way sub-solidus lower crystallization conditions (auto-metamorphism) were maintained and could have originated the subsolidus exsolution process described above.

\section{GEOTHERMOMETRY AND GEOBAROMETRY}

Applying the equations of Wood and Banno (1973) and Maxey and Vogel (1974) to calculate reequilibrium temperatures, strong variations in the $\mathrm{Kd}$ values (distribuition coefficient for coexisting OPX and $\mathrm{CPX}$ ) were obtained. The Kd values calculated for the Várzea Alegre samples ranging from 0.44 to 0.66 are compatible to metamorphic processes. This indicates variable and higher crystallization pressures than those calculated for the Bushveld pyroxenes (depth of about $20 \mathrm{Km}$; Burns 1985). This may be due to the complex crystallization and diffusion process they underwent. The absence of garnets and the $\mathrm{Al}_{2} \mathrm{O}_{3}$-contents of $\mathrm{CPX}$ generally lower than $3 \%$ confirm crystallization conditions below $20 \mathrm{Km}$ (Le Bas 1962).

Crystallization temperatures were obtained using the following mineral pairs: OPX-CPX, amphibole - plagioclase, ilmenite - magnetite and plagioclase - K - feldspar (data from Medeiros 1999). The pyroxene geothermometer yielded temperatures of approximately $850^{\circ} \mathrm{C}$, which in turn is compatible with subsolidus reequilibrium temperatures found in the literature (Lindsley \& Munoz 1969). In the intermediate lithotypes, the pair plagioclaseamphibole yielded temperatures around $750^{\circ} \mathrm{C}$, which could be considered as an equilibrium temperature. Lower subsolidus temperatures, ranging from $305^{\circ} \mathrm{C}$ to $550^{\circ} \mathrm{C}$, obtained for the pairs: ilmenite-magnetite and plagioclase-K-feldspar are related to reequilibrium processes in a late phase.

Using different empirical calibration methods 

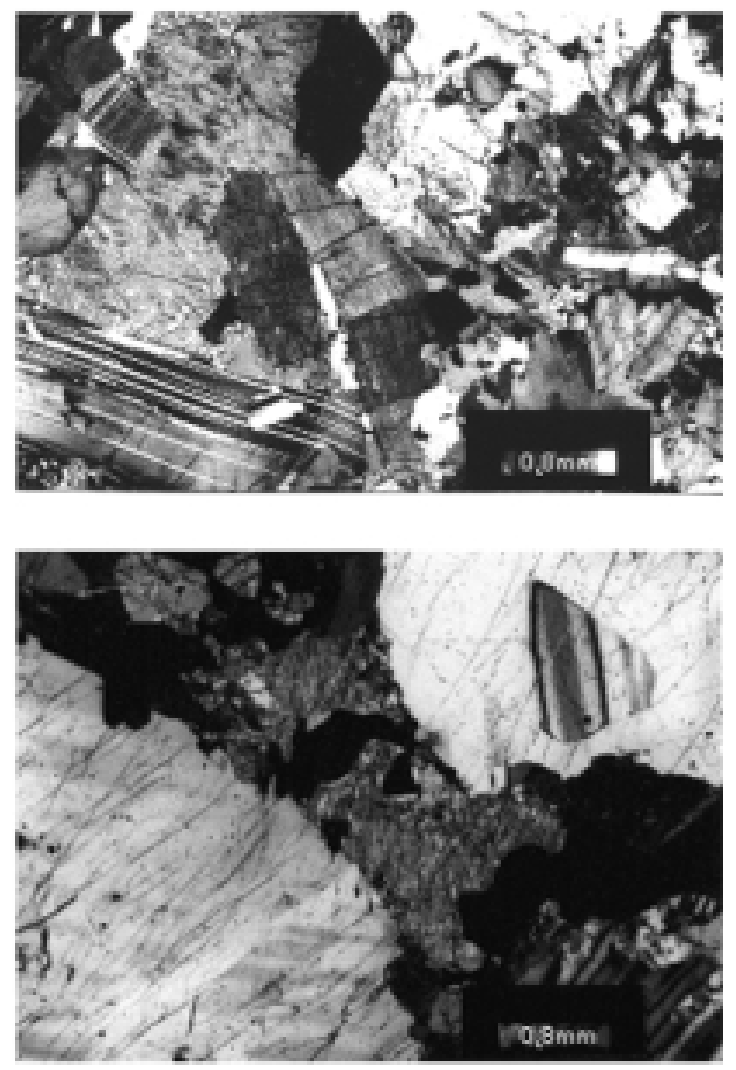

Figs. 14-15 - (Fig. 14) - Kink banded augite crystal suggesting a solidification previous to the mingling of the contrasting crystal mushes. (Fig. 15) - Exsolution lamellae of ilmenite, CPX and OPX parallel to the (100) plane indicate a Ti-, Fe- and/or Caricher primary compositions of Bushveld type pyroxenes.

of Al-contents in amphiboles Medeiros (1999) obtained crystallization pressures around $6 \mathrm{~Kb}$.

$\mathrm{Zr}$ and $\mathrm{P}_{2} \mathrm{O}_{5}$ saturation levels of the VAIC charnoenderbites from the outer rim (Mendes et al. 1999) indicate magmatic crystallization temperatures around $950^{\circ} \mathrm{C}$. Subsolidus temperatures, estimated through the ilmenite - magnetite and plagioclase - alkali feldspar pairs, were close to $550^{\circ} \mathrm{C}$ and $630^{\circ} \mathrm{C}$. Calculated $\mathrm{O}_{2}$-fugacity is consistent with highly reducing conditions, which are confirmed by the low $\mathrm{Mg} /(\mathrm{Mg}+\mathrm{Fe})$ ratios of the rocks. Estimated crystallization pressures are slightly higher than those estimated for the inner domain and range from 6.5 to $7 \mathrm{~Kb}$ (data from Mendes et al. 1999).

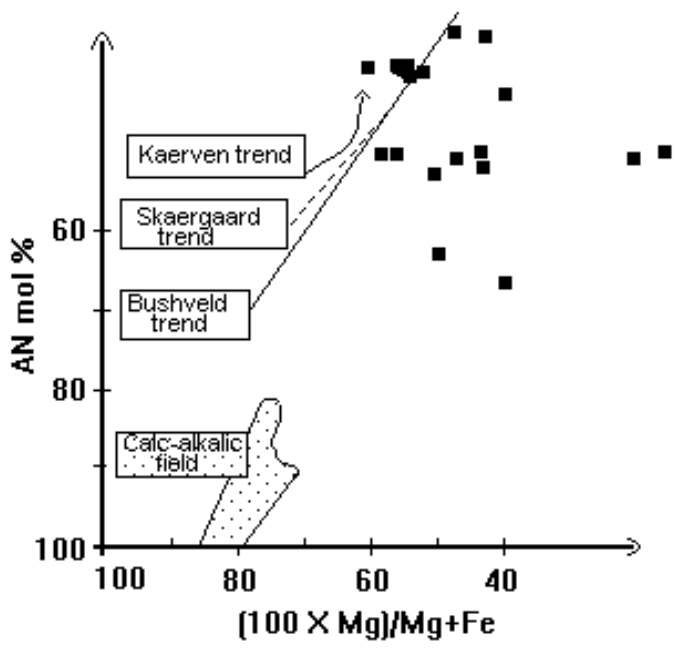

Fig. 16-Coexisting CPX and plagioclase compositions from the Varzea Alegre pluton, contrasted with trends from other tholeiitic sequences (Kaerven, East Greenland ; Bushveld and Skaergaard; modified after Burns 1985).

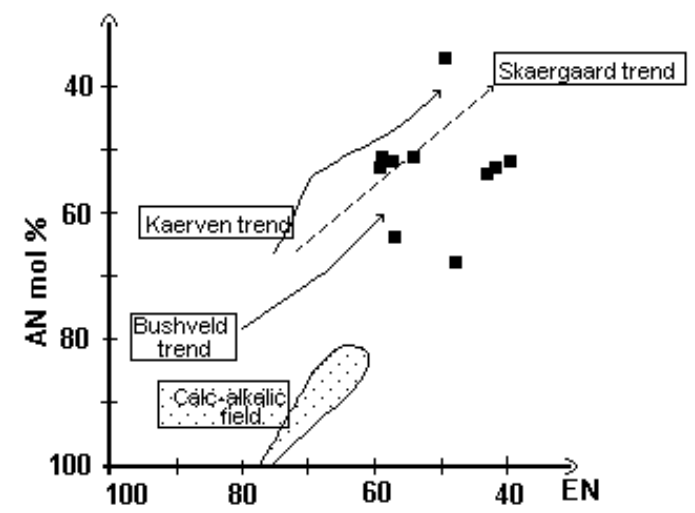

Fig. 17 - Coexisting plagioclase and OPX compositions from the Varzea Alegre pluton, contrasted with trends from other tholeiitic sequences (Kaerven, East Greenland ; Bushveld and Skaergaard; modified after Burns 1985).

\section{CONCLUSIONS}

The nearly circular shaped VAIC shows a concentric distribution of intermediate to acidic rocks surrounding a central portion of gabbroic composition. The first magmatic pulse consists of dark green mega- 


\section{TABLE III}

Representative Microprobe analyses of CPX.

\begin{tabular}{l|rrrrrrrrr}
\hline & VA-119 & VA-119 & VA-09 & VA-62 & VA-34 & VA-34 & VA-34 & VA-34 & VA-34 \\
\hline $\mathrm{SiO}_{2}$ & 52.24 & 52.48 & 51.47 & 52.76 & 52.01 & 50.64 & 50.77 & 51.64 & 51.39 \\
$\mathrm{TiO}_{2}$ & 0.13 & 0.08 & 0.13 & 0.15 & 0.18 & 0.32 & 0.25 & 0.25 & 0.10 \\
$\mathrm{Al}_{2} \mathrm{O}_{3}$ & 1.55 & 1.19 & 1.28 & 1.42 & 1.36 & 3.19 & 2.99 & 2.17 & 1.19 \\
$\mathrm{CaO}$ & 22.88 & 23.04 & 19.70 & 21.17 & 22.39 & 22.44 & 18.53 & 22.72 & 10.27 \\
$\mathrm{MgO}$ & 13.18 & 14.06 & 11.76 & 11.97 & 13.91 & 12.22 & 12.90 & 13.22 & 16.20 \\
$\mathrm{FeO}$ & 8.79 & 8.80 & 13.91 & 12.80 & 9.15 & 10.78 & 14.36 & 10.65 & 19.97 \\
$\mathrm{MnO}$ & 0.74 & 0.50 & 0.46 & 0.44 & 0.65 & 0.32 & 0.15 & 0.54 & 0.62 \\
$\mathrm{~K}_{2} \mathrm{O}$ & 0.00 & 0.00 & 0.10 & 0.00 & 0.00 & 0.00 & 0.00 & 0.00 & 0.00 \\
$\mathrm{Na} 2 \mathrm{O}$ & 0.47 & 0.44 & 0.32 & 0.53 & 0.43 & 0.46 & 0.42 & 0.36 & 0.18 \\
$\mathrm{BaO}$ & 0.09 & 0.02 & 0.04 & 0.00 & 0.00 & 0.02 & 0.00 & 0.00 & 0.01 \\
$\mathrm{Total}$ & 100.07 & 100.61 & 99.17 & 101.24 & 100.08 & 100.37 & 100.39 & 101.55 & 99.93 \\
& & & & & & & & & \\
$\mathrm{Si}$ & 1.949 & 1.942 & 1.973 & 1.969 & 1.937 & 1.892 & 1.907 & 1.904 & 1.947 \\
$\mathrm{Al}^{+4}$ & 0.051 & 0.052 & 0.027 & 0.031 & 0.060 & 0.108 & 0.093 & 0.094 & 0.053 \\
$\mathrm{Al}^{+6}$ & 0.017 & 0.000 & 0.031 & 0.032 & 0.000 & 0.032 & 0.039 & 0.000 & 0.000 \\
$\mathrm{Ti}_{\mathrm{Fi}}^{+2}$ & 0.004 & 0.002 & 0.004 & 0.004 & 0.005 & 0.009 & 0.007 & 0.007 & 0.003 \\
$\mathrm{~F}{ }^{+3}$ & 0.214 & 0.193 & 0.433 & 0.370 & 0.204 & 0.245 & 0.380 & 0.222 & 0.572 \\
$\mathrm{Mn}$ & 0.060 & 0.079 & 0.013 & 0.029 & 0.081 & 0.091 & 0.071 & 0.106 & 0.061 \\
$\mathrm{Mg}$ & 0.023 & 0.016 & 0.015 & 0.014 & 0.021 & 0.010 & 0.005 & 0.017 & 0.020 \\
$\mathrm{Ca}$ & 0.733 & 0.776 & 0.672 & 0.666 & 0.772 & 0.680 & 0.722 & 0.727 & 0.915 \\
$\mathrm{Na}$ & 0.915 & 0.914 & 0.809 & 0.847 & 0.893 & 0.898 & 0.746 & 0.898 & 0.417 \\
& 0.034 & 0.032 & 0.024 & 0.038 & 0.031 & 0.033 & 0.031 & 0.026 & 0.013 \\
$\mathrm{wo}_{\mathrm{en}}$ & 49.14 & 48.53 & 42.27 & 44.97 & 47.78 & 49.25 & 40.35 & 48.62 & 21.90 \\
$\mathrm{fs}$ & 39.37 & 41.19 & 35.10 & 35.36 & 41.29 & 37.30 & 39.07 & 39.35 & 48.05 \\
\hline & 11.49 & 10.27 & 22.63 & 19.67 & 10.93 & 13.45 & 20.57 & 12.04 & 30.05 \\
\hline
\end{tabular}

porphyritic charnoenderbites, which in turn was intruded by a later bimodal pluton. The contact between the quartz dioritic to quartz monzodioritic rocks and the megaporphyritic granite is net-veined or ragged, resulting in mingling zones with variable proportions of contrasting rocks. The synchronous rise of the two contrasting magmas is mainly confirmed by: 1) petrographic and microchemical characteristics of the mafic minerals of the original tholeiitic magma; 2) the presence of complex mantled feldspars, acicular apatite and Ti-rich biotite as well as local corroded xenocrysts of mafic phases in the granite; 3) the presence of K-feldspar and quartz xenocrysts as well as blobs from the granite in the more mafic rocks.

Pre-existing (pre-mingling) crystals interacted with the contrasting magma resulting in the various hybrid textures described in this paper. In this way, early stages of mixing may be characterized.

These observations are in accordance with the statement of Barbarin and Didier (1992) that hybridization processes are specially effective in the plutonic environment, mainly due to interaction time between the contrasting magmas before cooling.

The combination of field, petrographic and geochemical data reveals the presence of at least two 


\section{TABLE IV}

Representative Microprobe analyses of OPX ( $b=b o r d e r)$.

\begin{tabular}{l|rrrrrrrr}
\hline & VA-09 & VA-10 & VA-62 & VA-63 & VA-34 & VA-34b & VA-34 & VA-34 \\
\hline $\mathrm{SIO}_{2}$ & 50.57 & 52.41 & 51.22 & 52.20 & 51.32 & 51.96 & 52.24 & 51.56 \\
$\mathrm{TiO}_{2}$ & 0.12 & 0.05 & 0.07 & 0.05 & 0.05 & 0.03 & 0.07 & 0.10 \\
$\mathrm{Al}_{2} \mathrm{O}_{3}$ & 0.60 & 0.49 & 0.30 & 0.96 & 0.93 & 0.96 & 1.02 & 0.87 \\
$\mathrm{CaO}$ & 1.08 & 0.36 & 0.55 & 0.38 & 0.52 & 0.63 & 0.53 & 0.53 \\
$\mathrm{MgO}$ & 15.98 & 20.39 & 16.60 & 20.64 & 18.95 & 19.05 & 19.76 & 19.30 \\
$\mathrm{FeO}$ & 30.67 & 25.32 & 29.69 & 24.84 & 26.91 & 27.88 & 26.76 & 26.57 \\
$\mathrm{MnO}$ & 0.89 & 1.32 & 1.46 & 0.56 & 0.63 & 0.81 & 0.81 & 0.96 \\
$\mathrm{~K}_{2} \mathrm{O}$ & 0.17 & 0.00 & 0.00 & 0.13 & 0.00 & 0.00 & 0.00 & 0.00 \\
$\mathrm{Na} 2 \mathrm{O}$ & 0.00 & 0.00 & 0.03 & 0.04 & 0.03 & 0.00 & 0.03 & 0.01 \\
$\mathrm{BaO}$ & 0.01 & 0.01 & 0.01 & 0.00 & 0.00 & 0.02 & 0.00 & 0.03 \\
$\mathrm{Total}$ & 100.09 & 100.35 & 99.93 & 99.80 & 99.34 & 101.34 & 101.22 & 99.93 \\
& & & & & & & & \\
$\mathrm{Si}$ & 1.970 & 1.977 & 1.988 & 1.972 & 1.967 & 1.957 & 1.960 & 1.964 \\
$\mathrm{Al}^{+4}$ & 0.028 & 0.022 & 0.012 & 0.028 & 0.033 & 0.043 & 0.040 & 0.036 \\
$\mathrm{Al}^{+6}$ & 0.000 & 0.000 & 0.001 & 0.015 & 0.009 & 0.000 & 0.005 & 0.003 \\
$\mathrm{Ti}_{\mathrm{Fi}}^{+2}$ & 0.004 & 0.001 & 0.002 & 0.001 & 0.001 & 0.001 & 0.002 & 0.003 \\
$\mathrm{Fe}$ & 0.979 & 0.780 & 0.954 & 0.772 & 0.840 & 0.837 & 0.805 & 0.818 \\
$\mathrm{Mn}$ & 0.021 & 0.019 & 0.009 & 0.013 & 0.023 & 0.041 & 0.034 & 0.028 \\
$\mathrm{Mg}$ & 0.029 & 0.042 & 0.048 & 0.018 & 0.020 & 0.026 & 0.026 & 0.031 \\
$\mathrm{Ca}$ & 0.928 & 1.146 & 0.960 & 1.162 & 1.083 & 1.070 & 1.105 & 1.095 \\
$\mathrm{Na}$ & 0.045 & 0.015 & 0.023 & 0.015 & 0.021 & 0.025 & 0.021 & 0.022 \\
& 0.000 & 0.000 & 0.002 & 0.003 & 0.002 & 0.000 & 0.002 & 0.000 \\
${ }^{+3}$ & & & Formula Units based on 6 Oxygens & & \\
$\mathrm{en}$ & 2.31 & 0.75 & 1.18 & 0.79 & 1.10 & 1.32 & 1.10 & 1.12 \\
$\mathrm{fs}$ & 57.54 & 59.07 & 49.56 & 59.60 & 55.70 & 55.35 & 57.19 & 56.60 \\
\hline & 50.15 & 40.18 & 49.26 & 39.61 & 43.21 & 43.34 & 41.70 & 42.29 \\
\hline
\end{tabular}

different series of igneous rocks. The first originated from the partial melting of the mantle. This was previously enriched in incompatible elements, low and intermediate REE and some HFS-elements. This first series produced hyperthene - gabbros, quartzdiorites to quartz-monzodiorites that underwent a second enrichment in LREE and incompatible elements due to the mingling with a crustal granitic magma. This mingling process changed the composition of the original mantelic magma towards a medium-K calc-alkalic magma to produce a series of basic to intermediate rock types.

The granitic magma from the second high-K, calc-alkalic magma originated from the partial melting of the continental crust, but with strong influence of mantle-derived melts due to crustal delamination. The coeval rise of the two magmas consisting of contrasting crystal mushes resulted in a restricted mingling between them, until the final emplacement as diapirs.

The depth difference between the intrusions of the outer (charnoenderbitic) and inner rims (bimodal pluton) is not larger than ca. three kilometers (3 $\mathrm{km} \sim 1 \mathrm{~Kb}$ ). The temperature difference is in the magnitude of ca. $100^{\circ} \mathrm{C}$. This means that the time gap of around $25 \mathrm{Ma}$ between the crystallization of 


\section{TABLE V}

Representative Microprobe analyses of Amphiboles.

\begin{tabular}{l|rrrrrr}
\hline & VA-10 & VA-10 & VA-160 & VA-119 & VA-06 & VA-202 \\
\hline $\mathrm{SiO}_{2}$ & 46.10 & 45.10 & 43.73 & 44.13 & 42.77 & 41.99 \\
$\mathrm{TiO}_{2}$ & 1.32 & 1.22 & 1.47 & 1.38 & 1.72 & 1.20 \\
$\mathrm{Al}_{2} \mathrm{O}_{3}$ & 8.37 & 10.30 & 9.92 & 10.26 & 11.09 & 10.10 \\
$\mathrm{FeO}$ & 13.96 & 13.71 & 16.12 & 14.40 & 16.82 & 18.79 \\
$\mathrm{MnO}$ & 0.00 & 0.36 & 0.52 & 0.25 & 0.35 & 0.57 \\
$\mathrm{MgO}$ & 13.76 & 13.40 & 11.49 & 13.15 & 10.44 & 9.27 \\
$\mathrm{CaO}$ & 11.67 & 12.16 & 12.24 & 11.89 & 11.53 & 11.10 \\
$\mathrm{Na}_{2} \mathrm{O}$ & 1.16 & 1.17 & 1.36 & 1.31 & 1.16 & 1.57 \\
$\mathrm{~K}_{2} \mathrm{O}$ & 1.07 & 1.14 & 1.37 & 1.22 & 1.53 & 1.57 \\
$\mathrm{Total}$ & 97.41 & 98.56 & 98.22 & 97.99 & 97.41 & 96.15 \\
$\mathrm{Si}^{\mathrm{iv}}$ & & & & & & \\
$\mathrm{Al}^{\mathrm{iv}}$ & 1.80 & 6.57 & 6.51 & 6.50 & 6.42 & 6.47 \\
$\mathrm{Al}^{\mathrm{vi}}$ & 0.26 & 1.43 & 1.49 & 1.50 & 1.58 & 1.53 \\
$\mathrm{Fe}^{+2}$ & 1.61 & 1.39 & 0.27 & 0.28 & 0.38 & 0.31 \\
$\mathrm{Fe}^{+3}$ & 0.11 & 0.27 & 0.25 & 0.31 & 0.33 & 0.33 \\
$\mathrm{Mg}$ & 3.03 & 2.91 & 2.55 & 2.88 & 2.34 & 2.13 \\
$\mathrm{Mn}$ & 0.00 & 0.04 & 0.07 & 0.03 & 0.02 & 0.04 \\
$\mathrm{Ti}_{\mathrm{Ca}}$ & 0.15 & 0.13 & 0.16 & 0.15 & 0.19 & 0.14 \\
$\mathrm{Na}-\mathrm{A}$ & 1.84 & 1.90 & 1.95 & 1.87 & 1.85 & 1.84 \\
$\mathrm{~K}$ & 0.33 & 0.33 & 0.39 & 0.37 & 0.26 & 0.38 \\
$\mathrm{Asite}$ & 0.20 & 0.21 & 0.26 & 0.23 & 0.29 & 0.31 \\
& 0.53 & 0.54 & 0.65 & 0.60 & 0.55 & 0.69
\end{tabular}

Formula Units based on $24(\mathrm{O}, \mathrm{OH}, \mathrm{F}, \mathrm{Cl})$

\begin{tabular}{l|llllll}
$\mathrm{XMg}$ & 0.65 & 0.68 & 0.59 & 0.66 & 0.52 & 0.47 \\
\hline
\end{tabular}

the two plutons (inner and outer rims) do not represent a remarkable change in the regional P-T conditions. The middle crust remained warm during a long post-collisional period, providing sub-solidus temperatures to reequilibrate most of the pyroxene crystals.

The evolution of calc-alkalic suites through magma mixing processes is recurrent and characteristic for the Neoproterozoic late- to post-collisional magmatism of the Ribeira Belt (Pedrosa-Soares \& Wiedemann-Leonardos, 2000). This may indicate an important underplating mechanism of mantle magmas at the end of the orogen, which was respon- sible for maintaining high crustal temperatures for a longlasting late orogenic period.

\section{ACKNOWLEDGMENTS}

The authors are particularly grateful to Isabel P. Ludka for the critical review of the manuscript. Fruitful discussions with other colleagues, particularly Júlio Cesar Mendes and Ariadne C. Fonseca were also of great help. The field work for this project was supported by the financial help of the Brazilian FINEP and CNPq (financial agencies). Most of the laboratory work was undertaken and 


\section{TABLE VI}

Representative Microprobe analyses of Biotites.

\begin{tabular}{l|rrrrr}
\hline & VA-09 & VA-10 & VA-62 & VA-119 & VA-160 \\
\hline $\mathrm{SiO}_{2}$ & 36.03 & 36.25 & 36.74 & 36.64 & 37.14 \\
$\mathrm{TiO}_{2}$ & 5.32 & 4.38 & 5.85 & 5.09 & 4.14 \\
$\mathrm{Al}_{2} \mathrm{O}_{3}$ & 13.31 & 13.93 & 13.81 & 13.95 & 14.09 \\
$\mathrm{FeO}$ & 18.52 & 16.50 & 17.85 & 16.26 & 18.23 \\
$\mathrm{MnO}$ & 0.13 & 0.00 & 0.14 & 0.16 & 0.15 \\
$\mathrm{MgO}$ & 12.14 & 12.89 & 11.95 & 13.39 & 12.89 \\
$\mathrm{BaO}$ & 0.59 & 0.84 & 0.45 & 0.66 & 0.64 \\
$\mathrm{CaO}$ & 0.09 & 0.25 & 0.00 & 0.07 & 0.07 \\
$\mathrm{Na}_{2} \mathrm{O}$ & 0.01 & 0.02 & 0.06 & 0.03 & 0.07 \\
$\mathrm{~K}_{2} \mathrm{O}$ & 9.48 & 9.56 & 9.86 & 9.65 & 9.59 \\
$\mathrm{Total}$ & 95.62 & 94.62 & 96.71 & 95.90 & 97.01 \\
$\mathrm{Si}^{\mathrm{iv}}$ & & & & & \\
$\mathrm{Al}^{\mathrm{iv}}$ & 5.52 & 5.56 & 5.53 & 5.53 & 5.57 \\
$\mathrm{Al}^{\mathrm{vi}}$ & 2.40 & 2.44 & 2.45 & 2.47 & 2.43 \\
$\mathrm{Fe}^{+2}$ & 0.53 & 0.51 & 0.65 & 0.58 & 0.47 \\
$\mathrm{Fe}^{+3}$ & 2.37 & 2.12 & 2.25 & 2.05 & 2.29 \\
$\mathrm{Mg}$ & 0.02 & 0.00 & 0.02 & 0.02 & 0.02 \\
$\mathrm{Ba}_{\mathrm{Ca}}$ & 2.77 & 2.95 & 2.68 & 3.01 & 2.90 \\
$\mathrm{Na}$ & 0.04 & 0.05 & 0.03 & 0.04 & 0.04 \\
$\mathrm{~K}$ & 0.01 & 0.04 & 0.00 & 0.01 & 0.01 \\
& 1.85 & 0.01 & 0.02 & 0.01 & 0.02 \\
& & & 1.87 & 1.86 & 1.84 \\
$\mathrm{XMg}$ & 0.53 & 0.58 & 0.54 & 0.59 & 0.56 \\
\hline
\end{tabular}

funded by the Department of Geochemistry of the University of Utrecht, in the Netherlands. We are also grateful for the help of CPRM (The Brazilian Geological Survey) for complementary geochemical data. Last but not least, thanks to all the students who participated in this project.

\section{RESUMO}

No final do ciclo tectônico que originou o segmento norte do Cinturão Móvel Ribeira (de idade Proterozóica Superior a Paleozóica), uma série de complexos plutônicos tardi- a pós-colisionais, consistindo de larga gama de litotipos, intrudiu todas as unidades metamórficas. O Complexo Intrusivo de Várzea Alegre é um desses com- plexos pós-colisionais. A intrusão mais jovem consiste de uma estrutura de multiplos estágios, envolvida por um largo anel de rochas charnoenderbíiticas megaporfirícas de posicionmento anterior.

A combinação de dados de campo, petrográficos e geoquímicos revela a presença de pelo menos duas séries distintas de rochas ígneas. A primeira foi originada por fusão parcial do manto. Este era previamente enriquecido em elementos incompatíveis, em ETR leves e intermediários e em alguns elementos HFS. Um segundo enriquecimento em ETR leves e elementos incompatíveis nessa série foi devido ao "mingling" com o magma granítico crustal. Esse processo de mingling mudou a composição do magma toleíítico original para um magma cálcio- 


\section{TABLE VII}

Representative Microprobe analyses of Feldspars.

\begin{tabular}{|c|c|c|c|c|c|c|c|}
\hline & VA-119 & VA-09 & VA-62 & VA-119 & VA-34 & VA-34 & VA-10 \\
\hline $\mathrm{SiO}_{2}$ & 64.05 & 63.95 & 63.07 & 57.68 & 55.22 & 55.35 & 55.20 \\
\hline $\mathrm{Al}_{2} \mathrm{O}_{3}$ & 18.46 & 18.63 & 18.59 & 26.30 & 28.61 & 28.21 & 28.21 \\
\hline $\mathrm{FeO}$ & 0.26 & 0.27 & 0.36 & 0.15 & 0.00 & 0.00 & 0.18 \\
\hline $\mathrm{BaO}$ & 0.27 & 1.40 & 0.96 & 0.04 & 0.00 & 0.07 & 0.04 \\
\hline $\mathrm{CaO}$ & 0.15 & 0.18 & 0.17 & 7.99 & 10.79 & 11.12 & 10.77 \\
\hline $\mathrm{Na}_{2} \mathrm{O}$ & 0.84 & 0.97 & 1.19 & 6.71 & 5.39 & 5.36 & 5.43 \\
\hline $\mathrm{K}_{2} \mathrm{O}$ & 15.53 & 15.41 & 14.99 & 0.48 & 0.31 & 0.35 & 0.23 \\
\hline Total & 99.56 & 100.81 & 99.33 & 99.35 & 100.32 & 100.46 & 100.06 \\
\hline $\mathrm{Si}^{+4}$ & 11.92 & 11.89 & 11.86 & 10.37 & 9.86 & 9.89 & 9.93 \\
\hline $\mathrm{Al}^{+3}$ & 4.05 & 4.08 & 4.11 & 5.62 & 6.10 & 6.08 & 6.03 \\
\hline $\mathrm{Ca}^{+2}$ & 0.03 & 0.01 & 0.02 & 1.61 & 2.14 & 2.12 & 2.06 \\
\hline $\mathrm{Fe}^{+2}$ & 0.04 & 0.01 & 0.02 & 0.03 & 0.04 & 0.03 & 0.02 \\
\hline $\mathrm{K}^{+1}$ & 3.69 & 3.56 & 3.52 & 0.08 & 0.06 & 0.08 & 0.06 \\
\hline $\mathrm{Na}^{+1}$ & 0.30 & 0.35 & 0.44 & 2.29 & 1.81 & 1.82 & 1.95 \\
\hline \multirow[t]{2}{*}{$\mathrm{Ba}^{+1}$} & 0.02 & 0.10 & 0.08 & 0.00 & 0.00 & 0.00 & 0.00 \\
\hline & \multicolumn{7}{|c|}{ Formula Units based on 32 Oxygens } \\
\hline Or & 91.83 & 91.04 & 88.67 & 2.01 & 1.50 & 1.99 & 1.47 \\
\hline $\mathrm{Ab}$ & 7.43 & 8.71 & 10.84 & 57.54 & 45.14 & 45.27 & 47.91 \\
\hline An & 0.74 & 0.25 & 0.49 & 40.45 & 53.36 & 52.74 & 50.61 \\
\hline
\end{tabular}

alcalino de médio-K, que produziu a suíte de rochas básicas a intermediária. O magma granítico da segunda suite cálcio-alcalina de alto-K foi originada da fusão parcial da crosta continental, mas sob forte influência dos líquidos de derivação mantélica.

Palavras-chave: Magma "mingling", magmatismo póscolisional, Cinturão Ribeira.

\section{REFERENCES}

AtKIns FB. 1969. Pyroxenes of the Bushveld intrusion, South Africa. Jour Petrol 10: 222-249.

BARBARIN B \& Didier J. 1992. Genesis and evolution of mafic microgranular enclaves through various types of interaction between coexisting felsic and mafic magmas. Trans Royal Soc Edib: Earth Sciences 83: 145-153.

Bayer P, Horn H, Lammerer B, Schmidt-Thomé R, Weber-Diefenbach K \& Wiedemann CM. 1986.
The Brasiliano Mobile Belt in Southern Espírito Santo (Brazil) and its igneous intrusions. Zentralblatt für Geologie und Paläontologie. Teil I 9/10: 1429-1439.

Bayer P, Schmidt-Thomé R, Weber-Diefenbach K \& HorN H. 1987. Complex concentric granitoid intrusions in the coastal mobile belt, Espirito Santo, Brazil: the Santa Angélica Pluton - an example. Geologische Rundschau 76(2): 357-371.

Best MG \& Mercy EL. 1967. Composition and cyrstallization of mafic minerals in the Guadalupe Complex, California. Amer Mineral 52: 437-474.

Bilal E, Nalini JR HA, Horn H, Correa-Neves JM, Giret A, Fuzikawa K, Fernandes ML, Mello F \& MoutTe J. 1998. Neoproterozoic Granitoid suites of Rio Doce Region, Brazil. In: International Conference on Basement Tectonics, 14, Ouro Preto. $A b$ stracts: 41-43.

Boynton WV. 1984. Cosmochemistry of the rare earth element: meteorite studies. In: Henderson P (Ed.); 
Rare Earth Element Geochemistry. Amsterdan: Elsevier, p. 63-114.

Brown GM. 1961. Co-existing pyroxenes in igneous assemblages: a re-evaluation of the existing data on tie-line orientations. Geologica Magmatica 8: 333343.

Brown GM \& Vincent EA. 1963. Pyroxenes from the late stages of fractionation of the Skaergaard Intrusion, East Greenland. Jour Petrol 4(2): 175-197.

BuRns LE. 1985. The border Ranges ultramafic and mafic complex, south central Alaska: cumulate fractionates of island arc volcanics. Can Jour Earth Sci 22: 10201038.

Campos Neto MC \& Figueiredo MCH. 1995. The Rio Doce Orogeny, Southeastern Brazil. Jour South Amer Earth Sci 8, 2: 143-162.

Cordani UG, Delhal J \& Ledent D. 1973. Orogéneses superposées dans la précambrien du Brésil Sudoriental (Etats de Rio de Janeiro et Minas Gerais). Rev Bras Geoc 3: 1-22.

Cunningham D, Alkmin FF \& Marshak S. 1998. A structural transect across the coastal mobile belt in the Brazilian highlands (latitude $20^{\circ} \mathrm{S}$ ): the roots of a Precambrian transpressional orogen. Precambriam Res 92: 251-275.

Deer WA, Howie MA \& Zussman MA. 1978. Rock Forming Minerals - Single chain silicates, 2A, New York: J. Wiley and Sons, Incorporation, 668 p.

Frey FA. 1984. Rare Earth Element Abundance in Upper Mantle Rocks. In: Henderson P (Ed.); Rare Earth Element Geochemistry. Amsterdan: Elsevier, p. 153196.

Fritzer T. 1991. Das Guaçuí Lineament und die Orogene Entwicklung des Zentralen Ribeira Belt (Espírito Santo, Brasilien). Münchener Geologische Hefte, 2, München: Friedrich Pfeil Verlag, 196p.

Hibbard MJ. 1995. Petrography to Petrogenesis. 1. Ed. New Jersey: Prentice Hall, 608p.

Kushiro I. 1960. Si-Al relation in clinopyroxenes from igneous rocks. Amer Jour Sci 258: 548-554.

LAGACHE M. 1983. The exchange equilibrium distri- bution of alkali and alkaline-earth elements between feldspars and hydrothermal solutions. In: Brown WL (Ed.); Feldspars and Feldspathoids. Reidel Publishing Company, p. 247-279.

LAmmerer B. 1987. Short notes an a structural section through the Ribeira Mobile Belt (Minas Gerais and Espírito Santo, Brazil). Zentralblatt. für Geologie und Palaontologie, Teil I 7/8: 719-728.

LE BAs MJ. 1962. The role of Aluminium in igneous clinopyroxenes with relation to their parentage. Amer Jour Sci 260: 267-288.

LindSLEY DH \& MunOZ JL. 1969. Subsolidus relations along the join hedenbergite-ferrosilite. Amer Jour Sci 267-A: 295-324.

LudKa IP, Wiedemann CM \& TöPfner C. 1998. On the origin of incompatible element enrichment in the Venda Nova Pluton, State of Espírito Santo, Southeast Brazil. Jour South Amer Earth Sci 11(5): 473486.

Machado N, Valladares CS, Heilbron M \& ValeRIANO C. 1996. U-Pb geochronology of the central Coastal Mobile Belt (Brazil) and implications for the evolution of the Brazilian Orogeny. Precambrian Res 79: $347-0361$.

Maxey LR \& Vogel TA. 1974. Compositional Dependence of the Coexisting Pyroxene Iron-Magnesium Distribution Coefficient. Contrib Mineral Petrol 43: 295-306.

Medeiros SR. 1999. Estudo Mineralógico, Petrológico, Geoquímico e Isotópico do Complexo Intrusivo de Várzea Alegre, ES. Unpublished PhD Thesis, IGEO/ UFRJ. Fed Univ. of Rio de Janeiro, 174 p.

Mendes JC, McReath I, Wiedemann CM \& FigueiREDO MCH. 1997. Charnockitóides do Maciço de Várzea Alegre: um novo exemplo do magmatismo cálcio-alcalino de alto-K no arco magmático do Esp. Santo. Rev Bras Geoc 27(1): 13-24.

Mendes JC, Wiedemann CM \& McReath I. 1999. Charnockitic magmatic rocks from the Várzea Alegre Massif, Espírito Santo, Southeast Brazil: conditions of formation. Rev Bras Geoc 29.

NwE YY. 1970. Electron-probe studies of the earlier py- 
roxenes and olivines from the Skaergaard intrusion, east Greenland. Contrib Mineral Petrol 55: 105-126.

Pedrosa-Soares AC, Wiedemann CM, Fernandes MLS, Faria LF de \& Ferreira JCH. 1999. Geotectonic Significance of the Neoproterozoic Granitic Magmatism in the Araçuaí Belt, Eastern Brazil: a model and pertinent questions. Rev Bras Geoc 29(1): 59-66.

Pedrosa-Soares AC \& Wiedemann-Leonaros CM. 2000. Evolution of the Araçuaí Belt and its connection to the Ribeira Belt, Eastern Brazil. In: CORDANI $\mathrm{U}$ (Ed.); Geotectonic Evolution of South America. $31^{\text {st }}$ IGC, p. 265-285.

Schmidt-Thomé R \& Weber-Diefenbach K. 1987. Evidence of frozen-in magma mixing in Brasiliano calc-alkaline intrusions: the Santa Angélica pluton, Southern Espírito Santo, Brazil. Rev Bras Geoc 17(4): 498-506.

Seidensticker U \& Wiedemann C. 1992. Geochemistry and Origin of Lower Crustal Granulite Facies Rocks in the Serra do Caparaó Region, Esp. Santo/ Minas Gerais, Brazil. Jour South Amer Earth Sciences 6, 4: 289-298.

Sluitner Z \& Weber-Diefenbach K. 1989. Geochemistry of Charnoenderbitic Granulites and Associated Amphibolitic Gneeisses in the Coast Region of Espírito Santo, Brazil. Zentralblatt fur Geologie und Paleontologie, Teil I, H 5/6: 917-931.

Söllner F, Weber-Diefenbach K \& Lammerer B. 1989. Brasiliano Age of a Charnoenderbitic Rock Suite in the Complexo Costeiro (Ribeira Mobile Belt), Espírito Santo, Brazil: Evidence from U-Pb Geochronology on Zircons. Zentralblatt fur Geologie und Paleontologie, Teil I, H 5/6: 933-945.

Söllner F, Lammerer B \& Weber-Diefenbach K. 1991. Die Krustenentwicklung in der Küstenregion Nördlich von Rio de Janeiro/Brasilien. Münchner Geologische Hefte 4: 100p.
Sun S-S \& McDonough WF. 1989. Chemical and isotopic systematic of oceanic basalts: implications for mantle composition and processes. In: Magmatism in the Ocean Basins. Geological Society Special Publication 42: 313-345.

Tuller, MP. 1993. Texto Explicativo da Folha SE.24-YC-VI, Colatina. In: MP Tuller (org.) Programa Levantamentos Geológicos Básicos do Brasil. DNPM/ CPRM Brasília. 163 p.

Wiedemann CM. 1993. The Evolution of the Early Paleozoic Late- to Post-Collisional Magmatic Arc of the Coastal Mobile Belt In The State of Espírito Santo, Eastern Brazil. An Acad Bras Ci 5(1): 163-181.

Wiedemann CM, Bayer P, Horn H, Lammerer B, Ludka IP, Schmidt-Thome $\mathrm{R} \&$ WeberDiefenbach K. 1986. Maciços intrusivos do sul do Espírito Santo e seu contexto regional. Rev Bras Geoc 16(1): 24-37.

Wiedemann CM, Medeiros SR \& VRiend S. 1992. The Várzea Alegre Pluton - Evidence of the primary tholeiitic nature of monzodiorites and norites of a hybrid calc-alkaline pluton in the Ribeira Mobile Belt (Espírito Santo, Brazil). In: Geowissenschaftliches Lateinamerika Kolloquium, 13, Munster. Abstracts 53.

Wiedemann CM, Mendes JC \& LudKa IP. 1995. Contamination of Mantle Magmas by Crustal Contributions - Evidence from the Brasiliano Mobile Belt in the State of Espírito Santo, Brazil. An Acad Bras Ci 67 (supl. 2): 279-292.

Wood BJ \& BANNO S. 1973. Garnet, orthopyroxene and orthopyroxene-clinopyroxene relationships in simple and complex systems. Contrib Mineral Petrol 42: 109-124. 